\title{
Modelling $\mathrm{U}-\mathrm{Pb}$ discordance in the Acasta Gneiss: implications for fluid-rock interaction in Earth's oldest dated crust
}

Kirkland, C.L. ${ }^{1}$, Johnson, T.E. ${ }^{1}$, Kinny, P.D. ${ }^{1}$, Kapitany, T. ${ }^{2}$

${ }^{1}$ School of Earth and Planetary Sciences, Curtin University, Perth, 6845, Australia

${ }^{2}$ Crystal World, Australian Mineral Mines Pty. Ltd., 13 Olive Road, Devon Meadows Victoria, 3977, Australia

Email: c.kirkland@curtin.edu.au

Abstract

The $\mathrm{U}-\mathrm{Pb}$ isotopic system in zircon is the tool of choice to interrogate high-temperature geological processes, yet this system has potential to investigate lower temperature fluid-rock interaction as well. In some cases, removal of radiogenic $\mathrm{Pb}$ is incomplete, potentially allowing regression of discordant $\mathrm{U}-\mathrm{Pb}$ data on a concordia diagram to determine both the age of crystallization and the timing of fluid-driven isotopic disturbance. However, in rocks preserving more complex histories, simple regression is not effective at resolving multiple $\mathrm{Pb}$ loss events. Here, we use a 'concordant-discordant comparison' (CDC) test to establish the times of U-Pb disturbance in the Acasta Gneiss Complex (AGC), Canada. AGC c. 4.03 to c. $3.40 \mathrm{Ga}$ orthogneisses experienced a long and complex post-crystallization history, for which $\mathrm{U}-\mathrm{Pb}$ zircon data reflects not only the heterogeneous nature of the rock, but also the varying degrees and duration of crustal reworking that inevitably involved open system processes. The CDC test calculates the similarity between the concordant age structure and a modelled age structure, the latter inferred from discordant analyses, over a wide range of potential disturbance times. Our analysis reveals concordant zircon components implying new growth and/or recrystallization at $3992 \pm 5,3501 \pm 6,3442 \pm 5$ and $3126 \pm 6 \mathrm{Ma}$. In addition, we establish episodes of radiogenic-Pb loss driven by fluid-rock interaction at $3150 \pm 50 \mathrm{Ma}$, and probably at $2875 \pm 50 \mathrm{Ma}$ and c. $2590 \mathrm{Ma}$. These Pb-loss episodes correlate with previously recognised events recording growth of zircon rims during metamorphism, granite emplacement, and unroofing. Pb-loss within the AGC shows an antithetic relationship in different samples that are in close geographic proximity. We suggest that zircon alteration and associated new growth effectively rendered those grains that underwent Pb-loss at a particular time less susceptible to alteration during the next episode of fluid interaction.

KEYWORDS: Zircon, Acasta Gneiss Complex, Pb-loss, U-Pb geochronology; Discordance

Introduction

$\mathrm{U}-\mathrm{Pb}$ isotopes are the system of choice to address many temporal aspects of our planet's formative history, founded in part on the physical robustness of the mineral zircon and its tendency to incorporate $\mathrm{U}$ but exclude $\mathrm{Pb}$ during initial crystallization (see U-Pb zircon publication metrics in Spencer et al., 
2016). However, the very process that permits radiogenic dates to be calculated, the slow decay of isotopes of $\mathrm{U}$ to $\mathrm{Pb}$, also causes radiation damage to the crystal structure of zircon over time (Holland and Gottfried, 1955). This radiation damage leads to radiogenic Pb loss from zircon and hence discordance between the $\mathrm{U}-\mathrm{Pb}$ isotopic systems, such that the extent of discordance in different parts of zircon grains typically correlates with the abundance of $U$ and accompanying non-formula elements (including common Pb) (Fig. 1) (Köppel and Sommerauer, 1974; Ludwig and Cooper, 1984). Discordance, which can be defined as the degree of dissimilarity between any pair of isotopic dates, is the principal measure by which open system alteration processes in zircon may be tracked (Geisler et al., 2002; Pidgeon et al., 2013; Stern et al., 1966).

Radiogenic- $\mathrm{Pb}$ loss is generally regarded as detrimental to $\mathrm{U}-\mathrm{Pb}$ geochronology, in particular where the goal is in determining a primary crystallization age. However, radiogenic- $\mathrm{Pb}$ loss and the resulting trends of discordant data on concordia diagrams offer the possibility to understand the timing of events that stripped Pb from zircon (Kirkland et al., 2017). In many cases this Pb mobility corresponds to important metamorphic, anatectic and/or fluid-mediated events (Morris et al., 2015; Zamyatin et al., 2017).

Figure 2 plots two different measures of discordance versus age for a global dataset of zircon $\mathrm{U}-\mathrm{Pb}$ analyses. In Figure 2a, the centroid $\left(\left[{ }^{207} \mathrm{~Pb} / 206 \mathrm{~Pb}\right.\right.$ age $-{ }^{238} \mathrm{U} / 206 \mathrm{~Pb}$ age $] /{ }^{207} \mathrm{~Pb} / 206 \mathrm{~Pb}$ age $\left.\mathrm{x} 100\right)$ of the analytical error ellipse is compared to age; in Figure $2 b$ the proximity of the edge of the $2 \sigma$ error ellipse to the concordia curve is used, whereby a zero value indicates an error ellipse that intersects this curve. These plots illustrate several salient points with regard to discordance: (i) For Neoproterozoic and younger zircons the discordance of the centroid increases consistent with the precision of the ${ }^{207} \mathrm{~Pb} / 206 \mathrm{~Pb}$ ratio decreasing, as ${ }^{238} \mathrm{U} /{ }^{206} \mathrm{~Pb}$ remains relatively more constant as it is dictated by standard defined calibration uncertainties (Fig. 2a). In contrast, the amount of discordance of the two-sigma ellipse is not significantly different between Archean versus younger zircons (Fig. 2b). (ii) Although older grains generally will have accumulated more radiation damage and younger analyses will be associated with greater relative imprecision, on average greater discordance of the error ellipse is not clear for older analyses. (iii) Normal discordance $\left({ }^{207} \mathrm{~Pb} /{ }^{206} \mathrm{~Pb}\right.$ age $>238 \mathrm{U} /{ }^{206} \mathrm{~Pb}$ age $)$ is vastly more prevalent than reverse discordance, consistent with a dominance of $\mathrm{Pb}$ loss over $\mathrm{Pb}$ gain.

Linear regression of discordant $\mathrm{U}-\mathrm{Pb}$ data resulting from episodic $\mathrm{Pb}$ loss has been used to calculate concordia intercept ages ever since the Wetherill (1956) and Tera and Wasserburg (1972) concordia diagrams were introduced, and since $\mathrm{Pb}$ loss by continuous diffusion was ruled out as the dominant process (c.f. Tilton, 1960). Although this approach is powerful, such discordia regressions become challenging or impossible to fit with any degree of confidence in more complex samples that have undergone multiple phases of radiogenic- $\mathrm{Pb}$ loss and/or that contain multiple age populations. In such situations, an approach that considers multiple regressions of discordant data against the concordant age structure may have greater success at resolving the absolute timing of $\mathrm{Pb}$ mobility. 
An important suite of rocks for which zircon $\mathrm{U}-\mathrm{Pb}$ geochronology has been an essential tool in understanding early terrestrial evolution, but one complicated by $\mathrm{U}-\mathrm{Pb}$ discordance, is the Acasta Gneiss Complex (AGC), Northwest Territories, Canada. The AGC contains the oldest known evolved rocks on Earth, with zircon U-Pb crystallization ages up to c. 4.03 Ga (Stern and Bleeker, 1998; Bowring and Williams, 1999; Reimink et al. 2014, 2016b). Consequently, these rocks provide important constraints on Hadean to Archean terrestrial evolution, including the timing of formation and early geochemical evolution of the continental crust and depleted mantle (Moorbath et al., 1997; Reimink et al., 2018; Reimink et al., 2014; Reimink et al., 2016a).

Several different age components have been identified among the orthogneisses of the AGC: at c. 4.20 Ga, 4.03-3.92 Ga, c. 3.75 Ga, 3.65-3.55 Ga, c. 3.4 Ga, and c. $2.95 \mathrm{Ga}$. The oldest identified components of the AGC, the Idiwhaa Tonalitic Gneisses (ITG), have crystallization ages of 4.03-4.02 Ga (Bowring and Williams, 1999; Mojzsis et al., 2014; Reimink et al., 2016a; Stern and Bleeker, 1998), whereas the oldest analyzed zircon, a xenocrystic zircon core in a younger granitoid sample, is c. 4.2 Gyr old (Iizuka et al., 2007b). These ages have been interpreted to represent times when crustal magmas were added to the AGC (Reimink et al., 2019). Nonetheless, there are significant challenges in making robust age determinations for rocks of the AGC, with issues related to the inherent complexity of its zircon populations. This complexity, that occurs on the scale of individual zircon grains and sub-grain domains, reflects a combination of factors, including different crystallisation ages, the presence of inherited cores, the development of overgrowths and/or resorption during high-grade metamorphism and/or hydrothermal alteration, and discordance of the $\mathrm{U}-\mathrm{Pb}$ isotopic systems due to multistage $\mathrm{Pb}$ loss (in particular early Pb loss; Reimink et al., 2019). These factors, along with physical mixing between rocks of different ages during deformation, and mixing/mingling of coexisting magmas, likely have contributed to the difficulty in assigning accurate and precise ages to rocks of the AGC, in particular its oldest components (Iizuka et al., 2007a). In an effort to resolve these difficulties and understand the timing of radiogenic- $\mathrm{Pb}$ mobility, we apply Pb-loss modelling to a formerly unstudied sample of the ITG and compare our results with existing data.

\section{Method}

Two different samples were investigated for $\mathrm{U}-\mathrm{Pb}$ geochronology and for both samples zircon grains were separated from a crushed sample by picking from a heavy liquid non-magnetic concentrate. Sample CWX was analysed by SIMS as follows: U-Pb analyses were undertaken using the SHRIMP II ion microprobe facility at the John de Laeter Centre, Curtin University. Operating procedures for U, Th, and $\mathrm{Pb}$ isotopic measurements using the SHRIMP II ion microprobe are detailed in Wingate and Kirkland (2010). Uranium concentrations and ${ }^{238} \mathrm{U} /{ }^{206} \mathrm{~Pb}$ calibration were determined using the 91500 reference zircon (Wiedenbeck et al., 1995). Nineteen analyses of the 91500 were obtained during the session and indicated an external spot-to-spot uncertainty (reproducibility) of $0.5 \%(1 \sigma)$, and a ${ }^{238} \mathrm{U} /{ }^{206} \mathrm{~Pb}^{*}$ calibration uncertainty of $0.3 \%(1 \sigma)$. Calibration uncertainties are included in both the errors of ${ }^{238} \mathrm{U} /{ }^{206} \mathrm{~Pb}^{*}$ ratios 
and dates listed in electronic appendix Table 1. Common Pb corrections were applied to all analyses using the measured ${ }^{204} \mathrm{~Pb}$ and the contemporaneous isotopic composition from Stacey and Kramers (1975) Pb evolution model. Five analyses of the OG-1 reference zircon were undertaken during the session and yielded a weighted mean ${ }^{207} \mathrm{~Pb}^{*} / 206 \mathrm{~Pb}^{*}$ date of $3467 \pm 5 \mathrm{Ma}(\mathrm{MSWD}=1.2)$, within uncertainty of the accepted age (Stern et al., 2009).

Sample AC-10 was analysed by Laser Ablation Quadrupole Inductively Coupled Plasma Mass Spectrometry at the John de Laeter Centre, Curtin University. Zircon grains were ablated using a Resonetics RESOlution M-50A-LR sampling system (incorporating a Compex 102 excimer laser) coupled to an Agilent 8900 ICPMS. After two cleaning pulses, and following 20 seconds of background analysis, samples were ablated for 30 seconds at a $5 \mathrm{~Hz}$ repetition rate using a $22 \mu \mathrm{m}$ spot with laser energy of 1.8 $\mathrm{J} / \mathrm{cm}^{2}$. The sample cell was flushed by ultrahigh purity $\mathrm{He}\left(323 \mathrm{~mL} \mathrm{~min}{ }^{-1}\right)$ and $\mathrm{N}_{2}\left(1.2 \mathrm{~mL} \mathrm{~min}^{-1}\right)$. During time-resolved processing, contamination resulting from inclusions and compositional zoning was monitored, and only the relevant part of the signal was integrated. The primary reference material used for U-Pb dating in this study was zircon standard OG-1 (3465.4 \pm 0.6 Ma Stern et al. (2009)), which has an ablation response similar to the Archaean grains of interest. Secondary standard zircon 91500 (1062.4 $\pm 0.4 \mathrm{Ma}$; Wiedenbeck et al. (1995)), GJ-1 (601.7 \pm 1.4 Ma; Jackson et al. (2004)), and Plešovice (337.13 \pm $0.37 \mathrm{Ma}$; Sláma et al. (2008)) yielded ${ }^{206} \mathrm{~Pb} /{ }^{238} \mathrm{U}$ ages within $2 \%$ of the accepted value when reduced using appropriate matrix matched standards (i.e. using a primary reference material for reduction with similar $\mathrm{U}$ content to the secondary reference material). The time-resolved mass spectra were reduced using the U$\mathrm{Pb}$ Geochronology data reduction schemes in IoliteTM (Paton et al., 2011), and in-house Microsoft Excel macros. No common lead corrections were deemed necessary for sample AC-10 due to low ${ }^{204} \mathrm{~Pb}$ counts.

128 Sample details

\section{Sample CWX}

130 This material was supplied from a specimen in the collection of Crystal World Australia and was collected from $65^{\circ} 10^{\prime} 25.9^{\prime \prime} \mathrm{N} 115^{\circ} 33^{\prime} 12.1^{\prime \prime} \mathrm{W}$ (Fig. 3) and is a leucosome-rich portion of a plagioclasequartz-hornblende-biotite-garnet-bearing mafic tonalite. The sample is from the same general 133 location as the ITG (Reimink et al., 2014), although given the complex gneissic layering that 134 juxtaposes several generations of gneisses at a decimetre scale (Reimink et al., 2016), may not directly correspond to the specific component investigated by Reimink et al. (2016). While previous wholerock major-element compositions for the ITG unit indicate moderate $\mathrm{SiO}_{2}$ (57.9-66.9 wt.\%), low $\mathrm{Al}_{2} \mathrm{O}_{3}(13.8-14.1$ wt.\%), high total iron (8.6-15.3 wt.\% FeOt) and low $\mathrm{Mg} \#(100 \times$ molar $\mathrm{MgO} /(\mathrm{MgO}$ $+\mathrm{FeO}=3-18$ ) (Reimink et al., 2014), the investigated sample is more felsic, reflecting the abundance of leucosome. The sample yielded subhedral to euhedral, brown, turbid, equant to acicular, zircon crystals, which are up to $300 \mu \mathrm{m}$ long, and have aspect ratios up to 6:1. Most zircon grains are rich in inclusions (mainly of apatite) and show a predominantly low CL-response, with rare blurred indications of what probably represents original concentric growth zoning (Fig. 4). Small patches of homogeneous high 
CL-response zircon are preserved in cores between low CL-response, inclusion-rich domains. Inclusionfree low CL-response rims overgrow core domains (Fig. 4). All grains show evidence for alteration and metamictization manifest as spongy inhomogeneous portions with residual patches of resorbed and relatively unaltered zircon in the cores of some grains. The altered portion of grains are probably composed of hydrolysed amorphous zircon and zircon crystallites (Rayner et al., 2005).

\section{Sample AC-10}

To further understand the veracity of the $\mathrm{Pb}$ loss modelling results, we also investigate a sample of Acasta gneiss from the collections of Oxford University. This sample, AC-10, was collected by Prof. Stephen Moorbath on 22nd July 1995 from a locality 150-200 m northwest of the Acasta camp (Moorbath et al., 1997). Sample AC-10 is a quartzofeldspathic gneiss with patches of pink feldspar. In thin section, sample AC-10 is weakly foliated and volumetrically dominated by plagioclase and quartz, with clots and highly discontinuous and irregular thin mafic layers comprising mostly chlorite and epidote. Accessory minerals include apatite and zircon.

156 Results

\section{SIMS (Sample CWX)}

158 The analyses are predominantly normally discordant, with only 12 out of 92 analyses $(13 \%)$ within $2 \sigma$ analytical uncertainty of concordia (Fig. 5; electronic appendix Table 1). The analyses define a broadly triangular shaped array when plotted on a Tera-Wasserburg diagram, spreading away from both paraHadean and Paleoarchean concordant components. Importantly, no single time of $\mathrm{Pb}$ loss (i.e. single 'event') can describe the distribution of all data points. Those analyses that are within analytical uncertainty of concordia range in age from 3994 to $3126 \mathrm{Ma}$, with probability peaks centred around c. $3950 \mathrm{Ma}$ (Group A), c. $3500 \mathrm{Ma}$ (Group B) and c. $3100 \mathrm{Ma}$ (Group C). Nonetheless, the spread within any of these concordant age components can be significant, implying either mobility of $\mathrm{Pb}$ or multiple punctuated growth events. The lack of any correlation between $U$ content and age, along with the dissimilarity in $\mathrm{U}$ contents between these concordant groups, supports an interpretation of punctuated growth for at least some of the concordant analyses. Additionally, measured versus calculated $\mathrm{Th} / \mathrm{U}$ (where calculated $\mathrm{Th} / \mathrm{U}$ is derived from the ${ }^{207} \mathrm{~Pb}^{*} / 206 \mathrm{~Pb}^{*}$ age and the measured ${ }^{208} \mathrm{~Pb} / 206 \mathrm{~Pb}$ ratio assuming an undisturbed system) is similar in the concordant analyses, except for a single high $\mathrm{f} 204 \%$ analysis (spot ID 41.2) (Fig. 5). This general correspondence between measured and calculated Th/U for Groups $\mathrm{A}, \mathrm{B}$ and $\mathrm{C}$ implies no significant ancient disturbance to the $\mathrm{Pb}$ isotope composition of these analysed volumes, and so supports the interpretation that the $\mathrm{U}-\mathrm{Pb}$ dates record growth rather than alteration (e.g. Kirkland et al., 2017; Pidgeon et al., 2017). A group of five analyses (Group A-1 and Group D-1) located on homogeneous, low CL-response, inclusion-free zircon defines a linear regression with an upper intercept at $3992 \pm 5 \mathrm{Ma}(\mathrm{MSWD}=0.39)$ and an imprecise Mesoproterozoic (c. $1440 \mathrm{Ma})$ lower intercept. These analyses have low common $\mathrm{Pb}(\mathrm{f} 204 \%<0.04 \%)$ and comparable $\mathrm{Th} / \mathrm{U}$ ratios $(\sim 0.69)$. Analyses of zircon defining the Group B component were located on high CL response core 
regions that appear texturally similar to the older Group A core regions. Two analyses (spot IDs 41.2 and 38.1) from this age group have high common $\mathrm{Pb}$, and a third is located on a region preserving blurred zonation (spot ID 25.1). The remaining four analyses define two weighted mean ${ }^{207} \mathrm{~Pb} * / 206 \mathrm{~Pb}^{*}$ age groups at $3501 \pm 6 \mathrm{Ma}(\mathrm{MSWD}=0.003$; Group B-2) and $3442 \pm 5 \mathrm{Ma}(\mathrm{MSWD}=0.001$; Group B-3). The youngest concordant analysis is situated on a rim and yields a ${ }^{207} \mathrm{~Pb} * / 206 \mathrm{~Pb} *$ age of $3126 \pm 6 \mathrm{Ma}$ (Group C-4).

The dates of $3992 \pm 5 \mathrm{Ma}, 3501 \pm 6 \mathrm{Ma}, 3442 \pm 5 \mathrm{Ma}$, and $3126 \pm 6 \mathrm{Ma}$ for concordant groups A/D-1, B-2, B-3, and C-4 respectively, yield the best estimates for the crystallization age(s) of the protoliths to the gneiss and/or the age(s) of metamorphism or recrystallization. Due to the complex initial age structure (Fig. 5), a substantial portion of the U-Pb age data $(87 \%)$ is not interpretable within a conventional discordia regression framework (e.g. Kirkland et al., 2017; Morris et al., 2015; Reimink et al., 2016b). Such a framework typically evaluates regression fit parameters (e.g. MSWD) to substantiate the timing of episodic Pb loss (Spencer et al., 2016). This sample illustrates the need for a tool to predict the most likely time of radiogenic- $\mathrm{Pb}$ mobility in more complex discordant $\mathrm{U}-\mathrm{Pb}$ populations.

\section{LA-ICPMS (Sample AC-10)}

194 Seventy-six analyses were undertaken on ten different grains from sample AC-10. The data are mainly concordant with only 19 analyses outside of $2 \sigma$ analytical uncertainty of concordia, these discordant analyses predominantly appear to have lost radiogenic- $\mathrm{Pb}$, given their normal discordance (Fig. 6). The remaining data scatters along concordia, but there are several discrete age groups associated with specific grain internal textures. The oldest concordant component yields ${ }^{207} \mathrm{~Pb} / 206 \mathrm{~Pb}$ ages between 3630 and $\mathrm{c}$. $3500 \mathrm{Ma}$. These analyses have a general negative correlation between age and $\mathrm{U}$ content (younger ages higher $\mathrm{U}$ content), consistent with some of the spread on concordia for this age component being a function of ancient radiogenic- $\mathrm{Pb}$ loss near parallel to concordia rather than prolonged growth. In any case, the oldest statistically coherent component yields a weighted mean ${ }^{207} \mathrm{~Pb} / 206 \mathrm{~Pb}$ age of $3586 \pm 4(\mathrm{n}=$ 24 ; MSWD $=0.88$; Group I), interpreted as the age of magmatic crystallization. These analyses were located on core regions with indications of oscillatory zonation (Fig. 7). Another concordant component clusters around concordia with a weighted mean ${ }^{207} \mathrm{~Pb} /{ }^{206} \mathrm{~Pb}$ age of $3396 \pm 10(\mathrm{n}=5$; MSWD $=0.58$; Group M1), this group is associated with a single euhedral, high length to width oscillatory zoned grain as well as overgrowths. This group is interpreted to reflect partial melting, new zircon growth of discrete grains, as well as modification to pre-existing zircon. Other discrete concordant components have

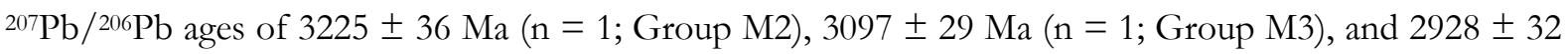
$\mathrm{Ma}(\mathrm{n}=2 ; \mathrm{MSWD}=0.22$; Group M4). Group M2 is associated with the core of a grain which has radial fractures, that are interpreted to have facilitated radiogenic- $\mathrm{Pb}$ loss, and hence this date likely reflects $\mathrm{Pb}$ loss (Fig. 7). Groups M3 and M4 are both associated with edges of grains and are interpreted to reflect periods of metamorphic zircon growth / recrystallization. Those analyses that spread between these groups are interpreted to have undergone variable degrees of ancient radiogenic- $\mathrm{Pb}$ loss (Group P). 
215

1

2216

3217

\section{Discussion}

In order to extract additional information on the post-crystallization history of the AGC from the high proportion of discordant zircon analyses that may not be otherwise apparent from the concordant subset, we explore in detail the $\mathrm{U}-\mathrm{Pb}$ systematics of sample CWX. We utilize a concordant-discordant comparison test (CDC) (Kirkland et al., 2017) to evaluate the most likely time(s) of radiogenic $\mathrm{Pb}$ loss and compare the results of the CDC test for sample CWX to the results of a series of modelled zircon populations of increasing complexity to demonstrate the sensitivity and efficacy of this test.

222 The CDC test applies a Bayesian approach, by first utilizing the measured age of any concordant 223 population as a priori knowledge, and then comparing this age to the upper intercepts of regressions 224 through the discordant fraction of analyses for every possible time of $\mathrm{Pb}$ loss. The test makes the implicit assumption that the discordant population was derived from zircon with a similar age structure to the concordant population (Kirkland et al., 2017). For each discordant U-Pb analysis in a population, an upper concordia intercept may be calculated for a given time of disturbance. For each grain and for each successive time of $\mathrm{Pb}$ loss, the resultant modelled population can be compared to the concordant population. A number of different non-parametric statistical tests could be employed to compare the concordant age structure with the modelled age populations. Here we use the "likeness" metric of Satkoski et al., (2013), which quantifies the degree of overlap between pairs of probability density plots (PDPs). The "likeness" metric represents the similarity between two unitized PDPs, and is calculated as one minus the sum of the absolute differences between all PDP values divided by two. A similarity value of 1 represents matching concordant and modelled age probability density values, whereas a value of zero indicates dissimilarity. This procedure is then repeated using different assumed times of disturbance, and the similarity function computed across the entire range of possible times of $\mathrm{Pb}$ loss. Analysis of this data then defines the most likely time of radiogenic $\mathrm{Pb}$ loss, which corresponds to the closest similarity between the concordant and modelled population.

\section{Concordant-discordant comparison models}

In order to investigate both the sensitivity and systematics of the CDC test we ran a range of synthetic datasets subjected to variable degrees and timings of radiogenic Pb loss (Fig. 8).

Simple models

Models refer to those plots shown in figure 8. Model A: To begin, we chose a simple situation of a normally-distributed population of 40 concordant analyses with an age of $4.0 \mathrm{Ga}$ and a standard deviation of five million years. For this population we modelled a single Pb-loss event at 2.9 Ga that caused 30\% radiogenic $\mathrm{Pb}$ loss in all of the synthetic data. Running the modelled discordant population through the CDC test resolves a single well-defined similarity peak centred at $2.9 \mathrm{Ga}$. Unsurprisingly, the CDC test performs well in this scenario and is able to accurately determine the timing of $\mathrm{Pb}$ loss. The similarity structure of the CDC test function shows a slightly negative skew, which is a function of the shape of the 
concordia curve, whereby a regression through a younger modelled $\mathrm{Pb}$ loss time will lead to a shallower slope and greater variance in this slope to the Concordia curve for the next modelled $\mathrm{Pb}$ loss time.

Model B: We next modelled a situation in which half of the population of discordant zircon was subject to a second overprinting radiogenic $\mathrm{Pb}$ loss event. The model was structured such that 20 analyses of the original concordant $4.0 \mathrm{Ga}$ population lost $30 \% \mathrm{~Pb}$ at $2.9 \mathrm{Ga}$, and a second set of 20 analyses underwent two $\mathrm{Pb}$ loss events, losing $30 \% \mathrm{~Pb}$ at $2.9 \mathrm{Ga}$ and another $30 \% \mathrm{~Pb}$ at $1.9 \mathrm{Ga}$. The resultant $\mathrm{CDC}$ similarity function resolves the single stage of $\mathrm{Pb}$ loss at $2.9 \mathrm{Ga}$, along with a spurious peak at c. $2.2 \mathrm{Ga}$, offset some c. $300 \mathrm{Ma}$ from the true timing of the second $\mathrm{Pb}$ loss event. Examination of the concordia diagram that corresponds to this model shows clearly why such a spurious secondary similarity peak is present in the CDC test result. The spurious age represents the lower intercept of a secondary regression line joining the primary concordant population and the two stage synthetic data, as though the latter had experienced only single stage $\mathrm{Pb}$ loss. Unfortunately, the position of the secondary similarity peak will vary with the amount of, and timing of the overprinting $\mathrm{Pb}$ loss such that the true overprinting $1.9 \mathrm{Ga} \mathrm{Pb}$ loss event cannot be resolved.

Models C and D: represent variations on Model B in which higher proportions of analyses have undergone two episodes of $\mathrm{Pb}$ loss $(80 \%$ of analyses in model $\mathrm{C}$ and $100 \%$ in model $\mathrm{D}$ are two stage $\mathrm{Pb}$ loss). Model C produced a similar test result to Model B, correctly resolving the first stage of $\mathrm{Pb}$ loss at $2672.9 \mathrm{Ga}$, but with a larger spurious second-stage Pb loss peak, again at c. 2.2 Ga. Only in Model D where 268 no analyses recording single stage evolution does the CDC approach fail to capture the 2.9 Ga event, nor 269 any of the true $\mathrm{Pb}$ loss times.

270 Two population models

271 To further explore the performance of the CDC test in complex scenarios involving overprinting Pb loss, 272 we ran a similar sequence of models involving one or more $\mathrm{Pb}$ loss events affecting a mixture of two 273 concordant populations (at $4.0 \mathrm{Ga}$ and $3.5 \mathrm{Ga}$ ).

274 Model E replicates the simple situation in model A except two concordant components (20 grains with an age of $4.0 \mathrm{Ga}$ and 20 with an age of $3.5 \mathrm{Ga}$ ) are each losing $30 \% \mathrm{~Pb}$ at $2.9 \mathrm{Ga}$. The CDC test returns a well-defined similarity peak centred at the correct time of $\mathrm{Pb}$ loss. This model illustrates a situation where the CDC test is much better able to extract useful timing information, as no geologically meaningful single regression fit to all the data is possible using a simple discordia regression.

Models F, $\mathbf{G}$ and $\mathbf{H}$ are similar to models B and C, but again with the additional $3.5 \mathrm{Ga}$ age component 280 that has undergone $\mathrm{Pb}$ loss. Model $\mathrm{F}$ represents a situation where $50 \%$ of the $4.0 \mathrm{Ga}$ and $3.5 \mathrm{Ga}$ populations underwent $20 \% \mathrm{~Pb}$ loss at $2.9 \mathrm{Ga}$ and the remaining $50 \%$ underwent $30 \% \mathrm{~Pb}$ loss at $2.9 \mathrm{Ga}$, and then again at $1.9 \mathrm{Ga}$. Model $\mathrm{G}$ represents a situation where even more grains underwent two stages of $\mathrm{Pb}$ loss, with $20 \%$ of the grains undergoing a single $\mathrm{Pb}$ loss event at $2.9 \mathrm{Ga}$, and $80 \%$ of the grains 
experiencing Pb loss at both 2.9 Ga and again at $1.9 \mathrm{Ga}$. Model $\mathrm{H}$ considers an extreme situation where

The CDC test similarity spectra from models F, G, and $\mathrm{H}$ are comparable in that they all feature spurious secondary similarity peaks generated from fitting regressions through the two stage $\mathrm{Pb}$ loss data points. The secondary similarity peaks increase in height in relation to the proportion of two stage grains to single stage grains. The apparent ages of the similarity peaks correspond to the lower intercepts of regressions through the second stage $\mathrm{Pb}$ loss node and the concordant points. Importantly, as with the simple models, the first stage Pb loss event at $2.9 \mathrm{Ga}$ is accurately determined for models $\mathrm{F}$ and $\mathrm{G}$, and the CDC test is strongly weighted to resolve single stage events due to the geometry of the Tera-Wasserburg plot.

The combined results for models A, B, C, E, F and G illustrate that the CDC test is effective in determining accurately the time of the first stage of $\mathrm{Pb}$ loss even when only a very small number of analyses in the data set represent domains that experienced the single $\mathrm{Pb}$ loss event without additional $\mathrm{Pb}$ loss at a later time. However, the CDC test cannot deconvolve multiple overprinting $\mathrm{Pb}$ loss events if there are no such domains retained.

\section{Complex models}

Finally, we present five models to illustrate other features in the similarity spectra generated from the CDC test (Fig. 9). In Model I we take the same concordant age structure used in models E, F, G and H and introduce single stage $\mathrm{Pb}$ loss at both $2.9 \mathrm{Ga}$ and $1.9 \mathrm{Ga}$. This results in four batches of 10 grains each that have undergone respectively (i) Pb loss at $2.9 \mathrm{Ga}$ from an initial concordant age of $4.0 \mathrm{Ga}$, (ii) $\mathrm{Pb}$ loss at 2.9 Ga from 3.5 Ga grains, (iii) Pb loss at 1.9 Ga from 4.0 Ga grains and (iv) Pb loss at $1.9 \mathrm{Ga}$ from $4.0 \mathrm{Ga}$ grains. Plus an additional 20 grains from the first stage $(2.9 \mathrm{Ga})$ event are also subjected to a $30 \% \mathrm{~Pb}$ loss event at $1.9 \mathrm{Ga}$ in a second stage of $\mathrm{Pb}$ loss. The CDC test similarity plot defines a peak at 2.9 Ga, successfully identifying this as a Pb loss event, consistent with at least some of the population having undergone a single stage of $\mathrm{Pb}$ loss at this time. A broad peak at around c. $1.9 \mathrm{Ga}$ is also defined, consistent with the younger $\mathrm{Pb}$ loss event. The breadth of the c. $1.9 \mathrm{Ga}$ peak is partly a function of the length and shallowness of the slope of the projection back to concordia. The implications are that short projections result in greater confidence in the $\mathrm{CDC}$ test, and that older $\mathrm{Pb}$ loss events will be better resolved by the CDC test provided they are not fully overprinted. The peaks at 2.2-2.3 Ga and 1.1-1.2 $\mathrm{Ga}$ are spurious and the result of secondary $\mathrm{Pb}$ loss lines. It is important to note that the oldest significant peak on the CDC test similarity plot will always reflect a real event if any grains preserve only a single stage of $\mathrm{Pb}$ loss.

Model J presents a more complex situation whereby the $4.0 \mathrm{Ga}$ and $3.5 \mathrm{Ga}$ concordant populations lost $\mathrm{Pb}$ during events at $3360 \mathrm{Ma}$ (5\% loss), $2900 \mathrm{Ma}$ (10\% loss), and $1900 \mathrm{Ma}$ (10\% loss), and 10 of the grains that lost $\mathrm{Pb}$ at $3360 \mathrm{Ma}$ underwent a second stage of $\mathrm{Pb}$ loss at $2900 \mathrm{Ma}(10 \%$ loss), while another 10 underwent a third stage of $\mathrm{Pb}$ loss at $1900 \mathrm{Ma}$ (10\% loss). The resultant CDC test similarity spectrum 
is complex, although a few grains preserve a peak at $2.9 \mathrm{Ga}$, consistent with $\mathrm{Pb}$ loss at this time. Many other younger peaks are spurious, as is the long similarity tail towards younger apparent $\mathrm{Pb}$ loss ages, which is a consequence of the multiple phases of overprinting $\mathrm{Pb}$ loss bringing points from the older (4.0 $\mathrm{Ga}$ ) concordant age group into close proximity (in terms of $207 \mathrm{~Pb} / 206 \mathrm{~Pb}$ ratio) with the younger (3.5 Ga) concordant age component.

Model $\mathbf{K}$ applies a geologically realistic scenario and models two episodes of radiogenic- $\mathrm{Pb}$ loss of variable intensity from an original concordant $4000 \mathrm{Ma}$ population. The first event at $2900 \mathrm{Ma}$ results in a random amount of $\mathrm{Pb}$ loss between 0 and 20\%, whereas the second event at $1900 \mathrm{Ma}$ involves a random amount of $\mathrm{Pb}$ loss between 0 and 10\%. The CDC test similarity spectrum rises to greatest similarity at $2900 \mathrm{Ma}$, successfully resolving the age of the first $\mathrm{Pb}$ loss event. However, the second $\mathrm{Pb}$ loss event is not determined by the CDC test, as only grains that have seen both events record this overprint. Model $\mathbf{L}$ takes the same population as in Model $\mathrm{K}$ with the added complexity of a variable amount of recent radiogenic- $\mathrm{Pb}$ loss. Importantly, the $\mathrm{CDC}$ similarity spectra is essentially identical to model $\mathrm{K}$, resolving the same first stage of $\mathrm{Pb}$ loss age, albeit at a lower similarity.

Model M depicts variable $\mathrm{Pb}$ loss at $2900 \mathrm{Ma}$ and $1900 \mathrm{Ma}$ on $4.0 \mathrm{Ga}$ and $3.5 \mathrm{Ga}$ concordant populations. The degree of $\mathrm{Pb}$ loss during stage one is randomly set between 1 and $10 \%$, whereas during stage two it is randomly set between 0 and $10 \%$. The CDC test yields a similarity spectrum that rises to peaks at about $2.9 \mathrm{Ga}$ and $2.4 \mathrm{Ga}$ with minor $>3.0 \mathrm{Ga}$ peaks. The salient point in this model is that the oldest significant similarity peak (as in all other models) approximates the initial time of $\mathrm{Pb}$ loss.

\section{$\mathrm{Pb}$ loss models for the Acasta Gniesses}

We now apply a series of CDC tests to U-Pb geochronology datasets from the Acasta Gneiss. Uncertainties on the $\mathrm{Pb}$ loss model are estimated using bootstrapping (random sampling with replacement). In comparison one we apply the CDC test to all analyses from sample CWX that lie beyond $2 \sigma$ analytical uncertainty from concordia and that have f204 values less than $1 \%$. This includes 76 analyses but excludes three analyses with up to $6.5 \%$ f 204 , as the latter may be compromised due to the combined effects of $\mathrm{Pb}$ loss and common $\mathrm{Pb}$ incorporation. Specifically, their calculated age is overly reliant on the correct common $\mathrm{Pb}$ composition having been applied. The test compares this discordant population, modelled through various $\mathrm{Pb}$ loss events between zero and $4200 \mathrm{Ma}$, with the concordant components (i.e. those analyses within $2 \sigma$ analytical uncertainty of concordia). We exclude two analyses from the concordant group with $>1 \%$ f204 for the reason stated previously (Fig. 10).

349 The CDC test similarity plot (red line in Fig. 10) rises towards greatest similarity for recent (zero age) $\mathrm{Pb}$ 350 loss but also shows significant peaks at $3150 \pm 50 \mathrm{Ma}$ and $2870 \pm 50 \mathrm{Ma}$. As per our synthetic CDC 351 results, and assuming that at least some of the analyses are from domains that have only undergone a 352 single $\mathrm{Pb}$ loss event, the oldest peak in the similarity structure (c. $3150 \mathrm{Ma}$ ) likely reflects a real radiogenic $353 \mathrm{~Pb}$ loss event. The long tail on the recent $\mathrm{Pb}$ loss peak is comparable with models in which prolonged 
open system behaviour produced a broad similarity peak. More specifically, the recent broad similarity peak in the CWX data is a consequence of the presence of discordant analyses lying immediately to the right of the Paleoarchean (Group B) concordant component (Fig. 5). Analyses plotting within this region of Tera-Wasserburg space could reflect either recent $\mathrm{Pb}$ loss from Group B, ancient $\mathrm{Pb}$ loss from the oldest component (Group A), or some combination of these processes.

One mechanism to further evaluate this data is to split the CDC test into additional discrete components for comparison (Fig. 10). Comparison two evaluates the Group A concordant analyses and those discordant analyses (Group D) with a ${ }^{207 \mathrm{~Pb}} /{ }^{206} \mathrm{~Pb}$ age older than Group B (i.e. $>3450 \mathrm{Ma}$ ). Comparison three compares Group A with those Group D analyses with ${ }^{207} \mathrm{~Pb} /{ }^{206} \mathrm{~Pb}$ ages younger than, or the same age as, the Group B component (i.e. with ${ }^{207} \mathrm{~Pb} / 206 \mathrm{~Pb}$ age $\leq 3450 \mathrm{Ma}$ ). Comparison four compares concordant Groups B and C with those Group D analyses with a ${ }^{207} \mathrm{~Pb} / 206 \mathrm{~Pb}$ age $\leq 3450 \mathrm{Ma}$. The purpose of these additional comparisons is to reduce the effects of multi-stage $\mathrm{Pb}$ loss that are manifest in the similarity spectra as apparent recent Pb loss. In comparisons two and three, similarity peaks at 3150 $\mathrm{Ma}$ and $2870 \mathrm{Ma}$ are again resolved, but with the broad recent peak that was prominent in comparison one much reduced. Comparison four has an entirely different shape, rising to a single similarity peak at c. $980 \mathrm{Ma}$. These additional comparisons support our interpretation that the recent broad similarity peak in comparison $\mathrm{A}$ is principally a function of ancient $\mathrm{Pb}$ loss from the c. $4.0 \mathrm{Ga}$ component, which has generated ${ }^{207} \mathrm{~Pb} /{ }^{206} \mathrm{~Pb}$ ratios close to those of the Paleoarchean concordant component, and is unlikely to mainly reflect recent $\mathrm{Pb}$ loss. This interpretation is further supported by the lack of analyses plotting in the region outside (i.e. with higher ${ }^{238} \mathrm{U} /{ }^{206} \mathrm{~Pb}$ than) a discordia stretching from c. $4.0 \mathrm{Ga}$ to $1.4 \mathrm{Ga}$.

374 It is important to state that the CDC test takes a fundamentally different approach to $\mathrm{Pb}$ loss modelling 375 than the method advocated by Reimink et al., (2016b). The Reimink et al., (2016b) method is coded to distinguish discordia lines within a dataset, but uses no a priori information, rather than comparing discordant to concordant components. The Reimink approach has been demonstrated to be well suited to cases where long discordant tails are apparent in complex populations. However, in situations where the degree of $\mathrm{Pb}$ loss is not sufficient to generate a distinct tail or there is clusters rather than cords the method rapidly loses resolving power. Applying the Reimink et al., (2016b) algorithm to the CWX dataset results in a broad poorly resolved likelihood spectrum that reaches a maximum around $1800 \mathrm{Ma}$, essentially between the similarity peaks at zero and the early Archean resolved by the CDC test. A conspicuous shift in low likelihood levels around the c. 3150 Ma CDC test similarity peak is also indicated by this method. This difference in apparent $\mathrm{Pb}$ loss timings between these two approaches is likely a result of the clustered nature of the Acasta data, which appears better suited to interrogation using the CDC test.

387 Likelihood that the grains were affected by a single $\mathrm{Pb}$ loss event

388 It has been shown from the modelling above that a pre-requisite to acceptance that the similarity peaks 389 record real $\mathrm{Pb}$ loss events is that some grains, or analytical domains, must have been affected by a single 
stage of $\mathrm{Pb}$ loss. We propose two ways to evaluate this requirement, firstly an analysis of the alpha dose received by the zircon populations and secondly by means of regional CDC comparisons. With regard to alpha dose, if grains were at various stages of metamictization, their susceptibility to $\mathrm{Pb}$ mobility would also vary (Nasdala, 1998; Krogh, 1982). Variable susceptibility to $\mathrm{Pb}$ loss is conducive to analysis using the $\mathrm{CDC}$ test, as the probability of all grains undergoing the same degree of overprinting $\mathrm{Pb}$ loss is very low, and hence the influence of geologically meaningless similarity peaks is greatly reduced in real data sets (relative to peaks representing real $\mathrm{Pb}$ loss events). A plot of calculated apparent alpha dose for the CWX zircons demonstrates this point (Fig. 11). Sample CWX shows a wide range in the number of alpha events experienced by different domains within the zircon crystals at any given point in time, with most areas having values corresponding to a highly metamict state were they to have remained unannealed since crystallization (Murakami et al., 1991; Weber, 1990).

In order to make further comparisons of the timing of $\mathrm{Pb}$ loss events affecting the Acasta gneisses, the CDC test has been applied to several additional samples of the ITG. Sample TC-3, a tonalitic gneiss studied by Reimink et al., (2014), contains both unzoned and oscillatory-zoned zircon dated at c. 4.0 Ga, that is interpreted as the age of magmatic crystallization. This sample also contains metamorphic overgrowths and/or recrystallized domains dated at c. 3.2 Ga. Sample TC-3 shows less discordance than other samples of the ITG (95 of 160 analyses are within analytical uncertainty of concordia), prompting the suggestion that this sample largely avoided much of the fluid alteration that affected most other samples of the ITG (Reimink et al., 2016a). The similarity structure for the CDC test of this sample (Fig. 10) shows a prominent similarity peak at $3080 \mathrm{Ma}$, a minor peak at $2590 \mathrm{Ma}$, and a broad rise towards geologically recent times. The broad rise is comparable to that shown in sample CWX, which has been shown to be, at least in part, a function of ancient $\mathrm{Pb}$ loss affecting the older age component, bringing ${ }^{207} \mathrm{~Pb} / 206 \mathrm{~Pb}$ ratios into juxtaposition with those of a younger concordant component. Another previously reported sample of the ITG (sample JR12-141) shows greater discordance (7 of 25 analyses are within analytical uncertainty of concordia) (Reimink et al., 2016a). This sample was analysed by LA-ICP-MS rather than SIMS, and is from a more felsic sample than TC-3 (Reimink et al., 2019). The CDC test similarity spectrum (Fig. 10) has peaks at c. $2870 \mathrm{Ma}$ and c. $2590 \mathrm{Ma}$ along with a broad rise indicating recent apparent $\mathrm{Pb}$ loss.

418 On the basis of the repeated appearance of a c. $3150 \mathrm{Ma}$ similarity peak in the comparison test results 419 (tests one to three) for sample CWX, we interpret the similarity peak at c. $3150 \mathrm{Ma}$ to date a real 420 radiogenic $\mathrm{Pb}$ loss event. This peak is absent, however, from the CDC test spectrum from sample TC-3 which instead features a similarity peak at c. 3080 Ma. The latter is probably also geologically significant given that it is at the older end of the CDC test array for that sample and is thus much less prone to the effects of multiple phases of overprinting $\mathrm{Pb}$ loss and geologically spurious similarity peaks. At c. 2870 $\mathrm{Ma}$, the oldest similarity peak in sample JR12-141 is also present in the spectra from sample CWX, supporting the interpretation that this peak too represents the timing of a real episode of radiogenic $\mathrm{Pb}$ 
loss. Comparable CDC test peaks at c. $2590 \mathrm{Ma}$, in samples JR12-141 and TC3 are also suggestive of a real $\mathrm{Pb}$ loss event. However, as discussed previously, the broad rise to geologically recent times in the spectra from all samples cannot confidently be ascribed to single-stage recent $\mathrm{Pb}$ loss alone. Further verification of the CDC test $\mathrm{Pb}$ loss ages of $3150 \pm 50 \mathrm{Ma}$ and $2870 \pm 50 \mathrm{Ma}$ from sample CWX is provided by rim ages in sample AC-10, which indicate rims of broadly similar age.

\section{Implications for regional geology}

432 Although some much older (c. $4200 \mathrm{Ma}$ ) zircon xenocrysts have been identified within samples of felsic 433 gneiss from the AGC (Iizuka et al., 2006; Iizuka et al., 2007a; Iizuka et al., 2007b), various authors have 434 typical identified a c. 4030 Ma population as the oldest zircon components in layered gneisses of the AGC (Iizuka et al., 2009; Mojzsis et al., 2014; Reimink et al., 2019; Reimink et al., 2014; Reimink et al., 2016a; Stern and Bleeker, 1998). Mojzsis et al., (2014) considered that only c. 3960 Ma magmatic zircon crystals were in chemical equilibrium with their host rock, and hence viewed this age as the most likely time of crystallization for much of the AGC magmatic protoliths. Younger, c. 3600 Ma concordant ages from different AGC samples are attributed to zircon growth during high-grade metamorphic events (Bowring and Housh, 1995; Bowring et al., 1990; Guitreau et al., 2018; Iizuka et al., 2007a; Iizuka et al., 2007b) and also magmatism (Bauer et al., 2017; Reiminik et al., 2019). Subsequent to the emplacement of tonalitic protoliths at c. 4200-3920 Ma (Iizuka et al., 2006), a protracted history of tectono-metamorphic events overprinted the AGC (Bowring et al., 1989; Stern and Bleeker, 1998). Two early Archean thermal events dated at c. 3850-3720 Ma and 3660-3590 Ma involved igneous intrusion, melting and recrystallisation of older units (Bowring et al., 1989; Iizuka et al., 2006; Iizuka et al., 2007b). Later modifications include granitic intrusion and the formation of migmatites, with renewed growth of zircon at c. $3371 \mathrm{Ma}$ (Bleeker and Stern, 1997; Moorbath et al., 1997) and again later at c. $2900 \mathrm{Ma}$ (Stern and Bleeker, 1998). Deposition of supracrustal rocks (the Yellowknife Supergroup) over ancient basement rocks was accompanied by a renewed period of granitic magmatism at c. $2700 \mathrm{Ma}$, and followed by the intrusion of multiple Paleoproterozoic dyke swarms and c. 1800 Ma bodies of syenite (Firth et al., 1977; Sano et al., 1999; Reimink et al., 2019). This protracted history culminated in regional metamorphism associated with Wopmay tonalite intrusion between about 1800 and $1900 \mathrm{Ma}$ (Bleeker and Stern, 1997; Iizuka et al., 2007b).

Some of the interpreted ages of $\mathrm{Pb}$ loss identified using the $\mathrm{CDC}$ test correspond with geological events known to have affected the western margin of the Slave Province (Isachsen and Bowring, 1994). Specifically, the c. $3150 \mathrm{Ma}$ similarity peak is comparable to the age of a concordant $3126 \pm 12 \mathrm{Ma}$ zircon overgrowth (38.2) in ITG sample CWX, and a rim age of $3097 \pm 29 \mathrm{Ma}$, in sample AC-10. The CWX overgrowth mantles a metamict core with an apparent ${ }^{207} \mathrm{~Pb}^{*} / 206 \mathrm{~Pb}^{*}$ age of c. $3480 \mathrm{Ma}$. Around $120 \mathrm{~km}$ south east of Acasta River, the Augustus granite, an altered rock consisting of plagioclase, quartz, microcline and chloritized mafic minerals, yielded zircon with an upper intercept age of $3156 \pm 3 \mathrm{Ma}$, interpreted as the magmatic crystallization age (Henderson, 1998). Furthermore, a c. 3150 Ma age peak is 
evident from an analysis of detrital zircon from the Central Slave Cover Group (Sircombe et al., 2001). The widespread areal distribution of c. $3150 \mathrm{Ma}$ dates suggests that crystalline basement of this age was extensive (Ketchum et al., 2004).

Unroofing of the basement components of the Slave Craton by the late Mesoarchean is inferred from the widespread development of a c. 2900-2800 Ma cover sequence (Bleeker et al., 1999a; Bleeker et al., 1999b). This emergence and erosional unroofing has been considered to have occurred in an aggressive $\mathrm{CO}_{2}$-rich atmosphere (Bleeker et al., 1999a; Bleeker et al., 1999b; Sircombe et al., 2001). A causal link between this unroofing and the c. $2880 \mathrm{Ma} \mathrm{Pb}$ loss peak is plausible because the zircon in the AGC will have moved into a location accessible to near surface reactive fluids. Furthermore, the similarity peak at $2870 \pm 50 \mathrm{Ma}$ is comparable to ages of moderately deformed granites at c. $2875 \mathrm{Ma}$ in the vicinity of the AGC (Mojzsis et al., 2014; Stern and Bleeker, 1998), an age also comparible to rim growth in AGC sample AC-10.

474 Beginning at around $2600 \mathrm{Ma}$, the entire Slave Craton was affected by significant shortening, 475 characterized by broadly north-south structural trends, which arguably developed in response to far476 field stresses associated with collision at a distal active margin (Bleeker et al., 1999a; Bleeker et al., 477 1999b). Moderate overthickening of the crust led to high temperature, low pressure metamorphism 478 and associated widespread anatexis, culminating in extension at c. $2590 \mathrm{Ma}$ and the production of a 479 regional-scale granite bloom. A Pb mobility event at c. $2590 \mathrm{Ma}$ is comparable to the age of a tonalite 480 near Grant Lake in the Wopmay Orogen $(2583 \pm 6 \mathrm{Ma})$, some $30 \mathrm{~km}$ west of the Acasta River, which correlates with cessation of orogenesis throughout the Slave Province (Jackson et al., 2013).

\section{Process of radiogenic Pb loss in the Acasta Gneisses}

483 Comparing the data from different samples within the general area of the ITG, equating to a scale of tens 484 of metres, the dominant $\mathrm{Pb}$ loss age as determined by CDC analysis is not consistent (Fig. 10). This inconsistency, if interpreted in a geological framework, suggests that radiogenic $\mathrm{Pb}$ loss in the interval 3.4-2.2 Ga was highly localised. The $\mathrm{Pb}$ loss process appears to render certain rocks and their constituent zircon grains resistant to the next phase of overprinting $\mathrm{Pb}$ loss, while other samples remained susceptible. One explanation for this is episodic fluid flow that could have preferentially affected zircons that had reached a critical threshold of radiation damage. The scale of lithological heterogeneity and hence zircon average $\mathrm{U}$ content would strongly control the domain size of $\mathrm{Pb}$ loss susceptible versus resistant horizons. In some cases, we suggest that such fluid-mediated alteration can be associated with new zircon growth driven by the release of essential elements from the damaged grains (e.g. at c. 3150 $\mathrm{Ma}$ ). Surprisingly, the oldest component within sample CWX (Group A) has the highest calculated alpha dose trajectory, yet is concordant, which indicates either that annealing has occurred, that this component has been impermeable to reactive fluids, or that cryptic $\mathrm{Pb}$ loss and gain occurred (e.g. Kusiak et al., 2013). Experimental studies have shown that, depending on the level of initial damage, lattice recovery 
can occur at temperatures as low as $427^{\circ} \mathrm{C}$ (Ming et al., 2000). Additionally, discrete grains or grain domains may be isolated from further fluid interaction by being shielded by zircon overgrowths, thus limiting $\mathrm{Pb}$ mobility. In this way a rock, or specific mineral components within it, can be rendered less susceptible to overprinting radiogenic $\mathrm{Pb}$ loss than others in close proximity, until a specific interval of time has passed with attendant alpha damage or until dissolution of protective overgrowths has occurred. Fundamentally, such highly-localised cryptic overprinting $\mathrm{Pb}$ loss is probably related to initial inhomogeneities in the zircon chemistry, which presumably reflect intrinsic differences in bulk rock composition. Such differences in zircon chemistry would lead to different susceptibilities to radiogenic- $\mathrm{Pb}$ loss driven by fluids. Furthermore, it is well known that water by itself is not effective at removing $\mathrm{Pb}$ from metamict zircon, but $\mathrm{Na}$ or $\mathrm{HCl}$ solutions can rapidly strip radiogenic $\mathrm{Pb}$ from metamict zircon (Geisler et al., 2002; Nasdala, 1998; Nasdala et al., 2001). Hence, weathering solutions have been proposed as an effective agent of $\mathrm{Pb}$ loss (Pidgeon et al., 2017).

509 Zircon grains are multiphase systems with respect to the resistivity of domains with different Th and U 510 content to $\mathrm{Pb}$ loss (Nasdala et al., 1996). U-Pb discordance in zircon corresponds with complex internal 511 zircon morphologies, depletion in radiogenic- $\mathrm{Pb}, \mathrm{U}, \mathrm{Si}, \mathrm{Zr}$, Th and HREE, and gain of common $\mathrm{Pb}, \mathrm{Ca}$, $512 \mathrm{Fe}, \mathrm{Al}, \mathrm{LREE}$ and water. Such observations have led to a percolation model of radiation damage whereby 513 initial lattice damage is limited to random spots of $\alpha$ recoil-induced crystal defects. In such a situation, 514 element loss is by volume diffusion requiring high temperatures. After this point, recoil-damaged areas 515 increase in number until they join to form a continuous amorphous network that provides a pathway for 516 rapid fluid and element migration. This point, defined as the first percolation point, corresponds to an $\alpha$ 517 dose of around $3 \times 10^{18} \alpha$-decay events $\mathrm{g}^{-1}$ (Salje et al., 1999). As alpha damage progresses, the lattice 518 framework is further degraded resulting in the formation of lattice fragments that are surrounded by an 519 amorphous matrix. This is defined as the second percolation point, and corresponds to an $\alpha$-dose of

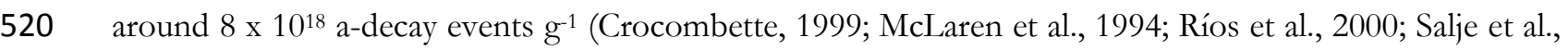
521 1999). Comparison of time versus calculated alpha dose plots for different zircon components within the 522 AGC, including those which have been measured for their REE contents (Mojzsis et al., 2014), indicates 523 that some of the highest apparent alpha doses occur in the most discordant analyses (Group D; sample 524 CWX), consistent with a percolation model of radiation damage (Fig. 12). However, in sample CWX, 525 Group A zircons show the highest calculated alpha doses, implying complexity in this model potentially 526 through shielding of susceptible core domains by zircon overgrowths or annealing.

527 Many U-Pb analyses from the AGC have been targeted on zircon overgrowths. Many of these analyses 528 have been interpreted as zircon growth and/or recrystallization during younger metamorphic events, the 529 majority within the $3.4-3.2 \mathrm{Ga}$ age range (Reimink et al., 2016b). A previously identified large-scale 530 metamorphic/fluid event within the AGC at c. 3.37 Ga (Moorbath et al., 1997; Reimink et al., 2014; Stern 531 and Bleeker, 1998), corresponding to intrusion of large granodioritic-granitic bodies a few km west of 532 ITG, may explain some of these AGC zircon overgrowths. However, it is noteworthy that the CDC tests 
533 do not indicate that any significant $\mathrm{Pb}$ loss occurred during that time interval or during that particular metamorphic/fluid event. Rather, the test results show that significant radiogenic-Pb mobility occurred later in the history of the AGC commencing at c. $3150 \mathrm{Ma}$ and more likely related to episodic highly localised fluid alteration in a strongly heterogeneous rock mass.

Implications for the evolution of the Acasta Gneiss Complex and early Earth processes

538 The AGC represents the oldest continental crust yet identified and contains concordant zircon 539 components with ages between $4.2 \mathrm{Ga}$ and $3.7 \mathrm{Ga}$. The age of the protoliths that comprise portions of 540 the AGC has been interpreted to be c. $3920 \mathrm{Ma}$, given the correspondence between zircon trace elements 541 and host rock chemistry (Mojzsis et al., 2014). However, an older component with an age of $4030 \mathrm{Ma}$ is 542 recognised, namely the ITG. Hadean zircons with ages up to $4.2 \mathrm{Ga}$ have been considered to be 543 inherited, generated during earlier episodes of crust formation (Reimink et al., 2014; Reimink et al., 544 2016a). Such Hadean input into the AGC is consistent with evolved Hf isotopic signatures and negative $545{ }^{142} \mathrm{Nd}$ anomalies (Reimink et al., 2018).

546 On the basis of time constrained zircon oxygen and whole-rock chemistry, Reimink et al., (2016a) 547 proposed that rocks of the AGC formed during 3.94 to $3.75 \mathrm{Ga}$ magmatic events through shallow partial 548 melting of hydrated mafic rocks (i.e., not in the garnet stability field). In addition, the $4.02 \mathrm{Ga}$ ITG, had 549 acquired its negative $\varepsilon \mathrm{Hf}$ signature from partial melting of enriched mantle or through interaction with 550 older Hadean mafic crust (Reimink et al., 2019; Reimink et al., 2018). Whole rock geochemistry and 551 petrogenetic modelling of the ITG are consistent with formation by shallow (low $P$ ) fractional crystallization of low- $\mathrm{H}_{2} \mathrm{O}$ basaltic magmas (Reimink et al., 2014). By contrast, Johnson et al., (2018) proposed that moderate degrees of partial melting of hydrated Fe-rich rocks in the uppermost few kilometres of a fractionated, dominantly mafic, Hadean crust was a plausible environment in which the rocks of the IGC formed. Such shallow melting implies geothermal gradients in excess of $\sim 4,000{ }^{\circ} \mathrm{C} \mathrm{GPa}-1$, which greatly exceed regional metamorphic rocks of any age worldwide, requiring a significant additional source of heat which was inferred to require bolide impact. Later, at c. 3.6 Ga, the AGC experienced the introduction of isotopically juvenile material that has been proposed as being derived from melting of hydrated mafic crust at significant depths $(>40 \mathrm{~km}$ ) (Reimink et al., 2019; Reimink et al., 2016a).

Discordance modelling implies that by $3.1 \mathrm{Ga}$ zircon crystals within the ITG had substantially different propensities to radiogenic- $\mathrm{Pb}$ loss. This grain-scale feature is consistent with a heterogeneous composition of the ITG by this stage in its development. Furthermore, to facilitate radiogenic- $\mathrm{Pb}$ loss at 3.1 Ga implies that the ITG was in an environment where near surface reactive fluids could interact with zircon to strip radiogenic $\mathrm{Pb}$ from unannealed crystals. Episodic $\mathrm{Pb}$ loss over the course of the next 200 $\mathrm{Ma}$ is consistent with a modified percolation model of radiation damage where shielding of zircon cores by new growth, and a fluid rich environment can account for the observed zircon U-Pb systematics. 
Granitoid magmas were emplaced into the AGC at c. 3.4 and c. 2.95 Ga. These felsic rocks have evolved compositions and are interpreted to have been derived through infracrustal partial melting mixed with juvenile additions (Reimink et al., 2019). Regional unroofing around the end of this magmatic period is consistent with further fluid-rock interaction and $\mathrm{Pb}$ loss at this time.

\section{Conclusions}

- SIMS U-Pb geochronology from a hitherto unstudied, legacy, sample of tonalitic gneiss, Acasta Gneiss Complex, yields concordant zircon components implying new growth and/or recrystallization at $3992 \pm 5,3501 \pm 6,3442 \pm 5$ and $3126 \pm 6$ Ma. However, significantly, a large component of the zircon population indicates highly disturbed $\mathrm{U}-\mathrm{Pb}$ isotope systematics consistent with multiple phases of ancient radiogenic $\mathrm{Pb}$ loss.

- Applying the Concordance-discordance comparison test to the same sample, we establish radiogenic- $\mathrm{Pb}$ loss at $3150 \pm 50 \mathrm{Ma}$ and likely also at $2870 \pm 50 \mathrm{Ma}$, while other published samples of the Acasta Gneiss also indicate Pb loss at c. $2590 \mathrm{Ma}$. These Pb loss events respectively correlate with other regional and local geological processes including growth of zircon rims and granite emplacement, unroofing, and late orogenic processes including additional pulses of granite generation.

- LA-ICPMS U-Pb geochronology grain mapping on zircon from a quartzofeldspathic gneiss yields magmatic zircon with crystallization age of $3586 \pm 4 \mathrm{Ma}$, and also records either new zircon growth / overgrowth or recrystallization / Pb loss at $3396 \pm 10 \mathrm{Ma}, 3225 \pm 36 \mathrm{Ma}, 3097$ $\pm 29 \mathrm{Ma}$, and $2928 \pm 32 \mathrm{Ma}$. Importantly, the latter two of these episodes are within uncertainty of the radiogenic- $\mathrm{Pb}$ loss events established by the concordance-discordance comparison test on sample CWX.

- Modelling of the sensitivity of the Concordance-discordance comparison test indicates it is most powerful in resolving older periods of radiogenic- $\mathrm{Pb}$ loss, but necessitates that overprinting $\mathrm{Pb}$ loss does not affect all zircon crystal equally. That is, some grains must remain unaffected by any multistage overprinting processes. Variable recent $\mathrm{Pb}$ loss principally serves to reduce concordance-discordance comparison similarity peaks rather than shifting them. Evaluation of calculated alpha doses for zircon grains of the Acasta Gneiss Complex indicate that it is highly unlikely that all grains would become susceptible to radiogenic $\mathrm{Pb}$ mobility at the same time and hence the concordance-discordance comparison test is effective in resolving at least the oldest $\mathrm{Pb}$ loss event.

- Different components of a gneiss will respond differently to fluid alteration events and associated radiogenic- $\mathrm{Pb}$ loss, influenced by the dissimilar zircon chemistry. This observation prompts a modified percolation model for zircon radiation damage. On obtaining a metamict crystal structure $\mathrm{Pb}$ is able to be effectively stripped from zircon by hydrothermal solutions. However, $\mathrm{Pb}$ mobility in some cases appears synchronous with new zircon growth, due to the release of 
necessary elements for zircon precipitation. In such cases shielding of susceptible core domains by zircon overgrowths is feasible and appears to limit $\mathrm{Pb}$ loss. Such model is able to account for the highly localised antithetic relationship between zircon $\mathrm{Pb}$ loss, where some domains may be losing $\mathrm{Pb}$ whereas other domains may be growing zircon and resistant to that episode of $\mathrm{Pb}$ loss. A natural consequence of this process is that through time, and alpha dose accumulation, that domains will oscillate between being robust to susceptible and back again to $\mathrm{Pb}$ mobility. The scale of the domain is a function of the compositional heterogeneity of the rock mass and hence its zircon cargo.

- On the basis of $\mathrm{Pb}$ loss modelling and the necessity of fluids to strip $\mathrm{Pb}$ from an unannealed zircon crystal structure, components of the Acasta Gneiss, resided at depths accessible to reactive fluids at least between c. $3.2 \mathrm{Ga}$ to $2.6 \mathrm{Ga}$.

\section{Acknowledgements}

616 The authors thank three anonymous reviewers who provided feedback on an earlier version. J. Reimink and M. Santosh are thanked for constructive comments that improved this work.

\section{Figure captions}

Figure 1a: Discordance (expressed as the percentage difference between the ${ }^{238} \mathrm{U} / 206 \mathrm{~Pb}$ and ${ }^{207} \mathrm{~Pb} / 206 \mathrm{~Pb}$ ages) versus $\mathrm{U}(\mathrm{ppm})$ for a dataset of 34,733 SIMS analyses of zircon. The red curve is a LOWESS (LOcally WEighted Scatterplot Smoothing; Cleveland, 1981) curve fit to the data and highlights a stepwise increase in discordance at higher U ppm. Figure 1b: Discordance (\%) versus f204(\%) from the same SIMS dataset. $\mathrm{f} 204 \%$ is the percentage of common (non-radiogenic) ${ }^{206} \mathrm{~Pb}$ as calculated from the measured ${ }^{204 \mathrm{~Pb}} /{ }^{206} \mathrm{~Pb}$ and the estimated contemporaneous composition of terrestrial $\mathrm{Pb}$ from the Stacey and Kramers Pb evolution model. The red curve denotes the LOWESS fit which shows a function that diverges to higher common $\mathrm{Pb}$ away from zero discordance. Data set available from http://www.dmp.wa.gov.au/geochron.

Figure 2a: Zircon age versus percentage discordance of centroid $\left(\left[{ }^{207} \mathrm{~Pb} /{ }^{206} \mathrm{~Pb}\right.\right.$ age / ${ }^{238 \mathrm{U} / 206 \mathrm{~Pb}}$ age] $/{ }^{207} \mathrm{~Pb} /{ }^{206} \mathrm{~Pb}$ age $\mathrm{x} 100$ ), contoured for data density. Figure $2 \mathrm{~b}$ : Zircon age versus percentage discordance of error ellipse. Age is based on ${ }^{207} \mathrm{~Pb} / 206 \mathrm{~Pb}$ ratio for analyses $>1600 \mathrm{Ma}$ and otherwise uses the ${ }^{238} \mathrm{U} / 206 \mathrm{~Pb}$ ratio. Analyses are TIMS, SIMS and LA-ICPMS, $\mathrm{n}=319,147$, extracted from Puetz et al., (2018). Both plots are contoured for data density.

Figure 3a: Sketch map of the Acasta Gneiss Complex (AGC) on the basis of age and composition after (Reimink et al., 2014). The yellow star marks the location of the Crystal Word specimen CWX. Figure 3b: Regional map of the Northwestern territories, Canada, with the AGC shown as a white star. The city of Yellowknife is shown as a circle that corresponds with the circle shown in c. Figure 3c: map of Canada showing the location of the Slave Province shown. The box indicates the location of map b.

638 Figure 4: Representative zircon images from CWX, a leucosome from the Acasta Gneiss. The lower 639 image is a false colour BSE image where green represents higher BSE response and higher U content, and 640 blue represents lower BSE response and lower U content. The upper shows an enlargement of grain 38 in 641 both BSE (left) and CL (right).

642 Figure 5: Tera-Wasserburg concordia diagram for zircons from sample CWX. Error crosses are at the 643 two sigma level. Green filled squares denote concordant Group A. Blue filled squares denote concordant 
Group B. The red filled square denotes concordant Group C. Grey filled squares (opaque and transparent) denote discordant analyses (Group D). The histogram on the Y-axis is for ${ }^{207} \mathrm{~Pb}^{*} /{ }^{206} \mathrm{~Pb}^{*}$ age. Those analyses defining a c. 4.0 Ga regression discussed in the text are Group A and opaque grey squares in Group D. Inset shows calculated $\mathrm{Th} / \mathrm{U}$ (based on ${ }^{208} \mathrm{~Pb}^{*} / 206 \mathrm{~Pb}^{*}$ and age) versus measured $\mathrm{Th} / \mathrm{U}$ with points scaled for common $\mathrm{Pb}$ content.

Figure 6: Tera-Wasserburg concordia diagram for zircons from sample AC-10. Error crosses are at the two sigma level. The histogram on the $\mathrm{Y}$-axis is for ${ }^{207} \mathrm{~Pb} /{ }^{206} \mathrm{~Pb}$ age. Weighted mean ${ }^{207} \mathrm{~Pb} /{ }^{206} \mathrm{~Pb}$ ages are shown in black filled boxes. Grey horizontal bars denote Pb-loss ages as estimated from the Concordantdiscordant comparison test on sample CWX.

Figure 7: Gridded ${ }^{207} \mathrm{~Pb} /{ }^{206} \mathrm{~Pb}$ ages from sample AC-10 as a transparent overlay on BSE images.

Figure 8: Concordant-discordant comparison test similarity spectra and corresponding Tera-Wasserburg plots for models $\mathrm{A}$ to $\mathrm{H}$. Black filled sections of the similarity spectra are times of $\mathrm{Pb}$ loss, grey filled curves are spurious peaks (secondary similarity peaks) caused by multiple phases of $\mathrm{Pb}$ loss affecting the same isotopic ratio. First stage $\mathrm{Pb}$ loss lines are shown as solid black lines, second stage lines are shown as dashed lines. Growth of secondary similarity peaks due to increase in pervasiveness of overprinting is highlighted by a rising dashed line through models B-D and F-H. Concordant starting material is indicated by the red filled squares. The first stage of $\mathrm{Pb}$ loss is shown by the blue filled squares, and the second stage of $\mathrm{Pb}$ loss by the green filled squares. Black filled squares are the time of radiogenic- $\mathrm{Pb}$ loss.

Figure 9: Concordant-discordant-comparison test similarity spectra and corresponding Tera-Wasserburg plots for models I, J, K, L and M. First stage Pb loss lines are shown as solid black lines, second stage shown as dashed line. Symbols as per figure 8. Brown squares denote third stage of Pb loss. Grey fill in Concordia plot for models $\mathrm{K}, \mathrm{L}$ and $\mathrm{M}$ is cone of discordance due to variable amounts of second stage $\mathrm{Pb}$ loss. Red similarity curve denotes model $\mathrm{L}$ with recent radiogenic- $\mathrm{Pb}$ loss.

Figure 10: Concordant-discordant-comparison (CDC) similarity values for samples of the Acasta Gneiss. Subset test of CWX permits evaluation of the effect of geologically spurious similarity peaks caused by juxtaposition of ${ }^{207} \mathrm{~Pb} /{ }^{206} \mathrm{~Pb}$ ratios by overprinting ancient $\mathrm{Pb}$ loss. Also shown is results of the Reimink et al., (2016b) Pb loss modelling method applied to CWX. Note the results of this method are expressed on the secondary $\mathrm{Y}$ axis as likelihood values. A probability density plot of zircon crystallization ages in the Slave Craton as recorded in the Canadian Geochronology Knowledgebase (https://www.nrcan.gc.ca) is provided on the upper $\mathrm{X}$-axis of the figure. The shaded confidence bar is a representation of probability of similarity peak for sample CWX being geologically meaningful.

Figure 11: Plot of calculated alpha dose (Murakami et al., 1991) versus accumulation duration for zircon crystals in sample CWX. The first and second percolation thresholds are shown with changes in grey scale (Salje et al., 1999). The yellow data points represent the values for analysed zircon grains/domains in sample CWX assuming alpha damage accumulation from their apparent ${ }^{207} \mathrm{~Pb}^{*} / 206 \mathrm{~Pb}^{*}$ age without annealing. Inset shows measured Th versus $\mathrm{U}$ for concordant zircon.

Figure 12: Plot of calculated alpha dose (Murakami et al., 1991) versus accumulation duration for the average composition of zircon crystals in the Acasta Gneiss. Zircons with REE compositional data are from Mojzsis et al., (2014). The first and second percolation points are shown with a change in grey scale (Salje et al., 1999). Note Group A has significantly higher alpha dose for all durations. Group D and discordant analyses of Mojzsis et al., (2014) are essentially identical. 


\section{Electronic Appendix}

Appendix Table 1: SHRIMP U-Pb zircon geochronology from sample CWX, Idiwhaa Tonalitic Gneiss,

Acasta Gneiss, Canada.

Appendix Table 2: LA-ICPMS U-Pb zircon geochronology from sample AC-10, Acasta Gneiss, Canada.

\section{References}

Bleeker, W. and Stern, R. (1997) The Acasta gneisses: an imperfect sample of Earth's oldest crust. Lithoprobe Rep. 56, 32-35.

Bleeker, W., Ketchum, J.W.F. and Davis, W.J. (1999a) The Central slave basement complex, Part II: Age and tectonic significance of high-strain zones along the basement-cover contact1. Canadian Journal of Earth Sciences 36, 1111-1130.

Bleeker, W., Ketchum, J.W.F., Jackson, V.A. and Vhieneuve, M.E. (1999b) The Central slave basement complex, part I: Its structural topology and autochthonous cover1. Canadian Journal of Earth Sciences 36, 1083-1109.

Bowring, S.A. and Housh, T. (1995) The earth's early evolution. Science 269, 1535-1540.

Bowring, S.A. and Williams, I.S. (1999) Priscoan (4.00-4.03 Ga) orthogneisses from northwestern Canada. Contributions to Mineralogy and Petrology 134, 3-16.

Bowring, S.A., Housh, T.B. and Isachsen, C.E. (1990) The Acasta gneisses: remnant of Earth's early crust. Origin of the Earth, 319-343.

Bowring, S.A., Williams, I.S. and Compston, W. (1989) 3.96 Ga gneisses from the Slave province, Northwest Territories, Canada. Geology 17, 971-975.

Cleveland, W.S. (1981) LOWESS: A program for smoothing scatter plots by robust locally weighted regression. The American Statistician, 35, 54.

Crocombette, J.P. (1999) Theoretical study of point defects in crystalline zircon. Physics and Chemistry of Minerals 27, 138-143.

Frith, R., Frith, R.A., and Doig, R., (1977) The geochronology of the granitic rocks along the Bear-Slave Structural Province boundary, northwest Canadian Shield, Canadian Journal of Earth Science, 14, 1356-1373.

Geisler, T., Pidgeon, R.T., Van Bronswijk, W. and Kurtz, R. (2002) Transport of uranium, thorium, and lead in metamict zircon under low-temperature hydrothermal conditions. Chemical Geology 191, 141-154.

Guitreau, M., Mora, N. and Paquette, J.L. (2018) Crystallization and Disturbance Histories of Single Zircon Crystals From Hadean-Eoarchean Acasta Gneisses Examined by LA-ICP-MS U-Pb Traverses. Geochemistry, Geophysics, Geosystems 19, 272-291.

Hammer, Ø., Harper, D.A.T. and Ryan, P.D. (2001) Past: Paleontological statistics software package for education and data analysis. Palaeontologia Electronica 4, XIX-XX.

Henderson, J.B. (1998) Geology of the Keskarrah Bay area, District of Mackenzie, Northwest Territories. Geological Survey of Canada, Bulletin 527, 122.

Holland, H.D. and Gottfried, D. (1955) The effect of nuclear radiation on the structure of zircon. Acta Crystallographica 8, 291-300.

Iizuka, T., Horie, K., Komiya, T., Maruyama, S., Hirata, T., Hidaka, H. and Windley, B.F. (2006) $4.2 \mathrm{Ga}$ zircon xenocryst in an Acasta gneiss from northwestern Canada: Evidence for early continental crust. Geology 34, 245-248. 
Iizuka, T., Komiya, T. and Maruyama, S. (2007a) Chapter 3.1 The Early Archean Acasta Gneiss Complex: Geological, Geochronological and Isotopic Studies and Implications for Early Crustal Evolution, in: van Kranendonk, M.J., Smithies, R.H., Bennett, V.C. (Eds.), Developments in Precambrian Geology. Elsevier, pp. 127-147.

Iizuka, T., Komiya, T., Johnson, S.P., Kon, Y., Maruyama, S. and Hirata, T. (2009) Reworking of Hadean crust in the Acasta gneisses, northwestern Canada: Evidence from in-situ Lu-Hf isotope analysis of zircon. Chemical Geology 259, 230-239.

Iizuka, T., Komiya, T., Ueno, Y., Katayama, I., Uehara, Y., Maruyama, S., Hirata, T., Johnson, S.P. and Dunkley, D.J. (2007b) Geology and zircon geochronology of the Acasta Gneiss Complex, northwestern Canada: New constraints on its tectonothermal history. Precambrian Research 153, 179-208.

Isachsen, C.E. and Bowring, S.A. (1994) Evolution of the Slave craton. Geology 22, 917-920.

Jackson, V.A., van Breemen, O., Ootes, L., Bleeker, W., Bennett, V., Davis, W.J., Ketchum, J.W.F. and Smar, L. (2013) U?Pb zircon ages and field relationships of Archean basement and Proterozoic intrusions, south-central Wopmay Orogen, NWT: implications for tectonic assignments. Canadian Journal of Earth Sciences 50, 979-1006.

Johnson, T.E., Gardiner, N.J., Miljković, K., Spencer, C.J., Kirkland, C.L., Bland, P.A. and Smithies, H. (2018) An impact melt origin for Earth's oldest known evolved rocks. Nature Geoscience 11, 795-799.

Kirkland, C.L., Abello, F., Danišík, M., Gardiner, N.J. and Spencer, C. (2017) Mapping temporal and spatial patterns of zircon U-Pb disturbance: A Yilgarn Craton case study. Gondwana Research 52, 39-47.

Krogh, T.E. (1982) Improved accuracy of U-Pb zircon ages by the creation of more concordant systems using an air abrasion technique. Geochimica et Cosmochimica Acta 46, 637-649.

Kusiak, M., Whitehouse, M.J., Wilde, S., Nemchin, A.A., Clark, C., (2013) Mobilization of radiogenic $\mathrm{Pb}$ in zircon revealed by ion imaging: Implications for early Earth geochronology, Geology 41, 291-294.

Köppel, V. and Sommerauer, J. (1974) Trace elements and the behaviour of the U-Pb system in inherited and newly formed zircons. Contributions to Mineralogy and Petrology 43, 71-82.

Ludwig, K.R. and Cooper, J.A. (1984) Geochronology of Precambrian granites and associated UTi-Th mineralization, northern Olary province, South Australia. Contributions to Mineralogy and Petrology 86, 298-308.

McLaren, A.C., Gerald, J.D.F. and Williams, I.S. (1994) The microstructure of zircon and its influence on the age determination from $\mathrm{Pb} / \mathrm{U}$ isotopic ratios measured by ion microprobe. Geochimica et Cosmochimica Acta 58, 993-1005.

Ming, Z., Ekhard, K.H.S., Gian Carlo, C., Hugues, L., Andrew, M.C., Jochen, S. and Rodney, C.E. (2000) Annealing of alpha-decay damage in zircon: a Raman spectroscopic study. Journal of Physics: Condensed Matter 12, 3131.

Mojzsis, S.J., Cates, N.L., Caro, G., Trail, D., Abramov, O., Guitreau, M., Blichert-Toft, J., Hopkins, M.D. and Bleeker, W. (2014) Component geochronology in the polyphase ca. 3920Ma Acasta Gneiss. Geochimica et Cosmochimica Acta 133, 68-96.

Moorbath, S., Whitehouse, M.J. and Kamber, B.S. (1997) Extreme Nd-isotope heterogeneity in the early Archaean - Fact or fiction? Case histories from northern Canada and West Greenland. Chemical Geology 135, 213-231. 
Morris, G.A., Kirkland, C.L. and Pease, V. (2015) Orogenic paleofluid flow recorded by discordant detrital zircons in the Caledonian foreland basin of northern Greenland. Lithosphere 7, 138-143.

Murakami, T., Chakoumakos, B.C., Ewing, R.C., Lumpkin, G.R. and Weber, W.J. (1991) Alphadecay event damage in zircon. American Mineralogist 76, 1510-1532.

Nasdala, L. (1998) Metamictization and U-Pb isotopic discordance in single zircons: A combined Raman microprobe and SHRIMP ion probe study. Mineralogy and Petrology 62, 1-27.

Nasdala, L., Beran, A., Libowitzky, E. and Wolf, D. (2001) The incorporation of hydroxyl groups and molecular water in natural zircon ( $\mathrm{ZrSiO} 4)$. American Journal of Science 301, 831-857.

Nasdala, L., Pidgeon, R.T. and Wolf, D. (1996) Heterogeneous metamictization of zircon on a microscale. Geochimica et Cosmochimica Acta 60, 1091-1097.

Pidgeon, R.T., Nemchin, A.A. and Cliff, J. (2013) Interaction of weathering solutions with oxygen and $\mathrm{U}-\mathrm{Pb}$ isotopic systems of radiation-damaged zircon from an Archean granite, Darling Range Batholith, Western Australia. Contributions to Mineralogy and Petrology 166, 511-523.

Pidgeon, R.T., Nemchin, A.A. and Whitehouse, M.J. (2017) The effect of weathering on U-Th$\mathrm{Pb}$ and oxygen isotope systems of ancient zircons from the Jack Hills, Western Australia. Geochimica et Cosmochimica Acta 197, 142-166.

Puetz, S.J., Ganade, C.E., Zimmermann, U. and Borchardt, G. (2018) Statistical analyses of Global U-Pb Database 2017. Geoscience Frontiers 9, 121-145.

Rayner, N., Stern, R.A. and Carr, S.D. (2005) Grain-scale variations in trace element composition of fluid-altered zircon, Acasta Gneiss Complex, northwestern Canada. Contributions to Mineralogy and Petrology 148, 721-734.

Reimink, J.R., Bauer, A.M. and Chacko, T. (2019) Chapter 15 - The Acasta Gneiss Complex, in: Van Kranendonk, M.J., Bennett, V.C., Hoffmann, J.E. (Eds.), Earth's Oldest Rocks (Second Edition). Elsevier, pp. 329-347.

Reimink, J.R., Chacko, T., Carlson, R.W., Shirey, S.B., Liu, J., Stern, R.A., Bauer, A.M., Pearson, D.G. and Heaman, L.M. (2018) Petrogenesis and tectonics of the Acasta Gneiss Complex derived from integrated petrology and $142 \mathrm{Nd}$ and $182 \mathrm{~W}$ extinct nuclide-geochemistry. Earth and Planetary Science Letters 494, 12-22.

Reimink, J.R., Chacko, T., Stern, R.A. and Heaman, L.M. (2014) Earth's earliest evolved crust generated in an Iceland-like setting. Nature Geoscience 7, 529-533.

Reimink, J.R., Chacko, T., Stern, R.A. and Heaman, L.M. (2016a) The birth of a cratonic nucleus: Lithogeochemical evolution of the 4.02-2.94Ga Acasta Gneiss Complex. Precambrian Research 281, 453-472.

Reimink, J.R., Davies, J.H.F.L., Waldron, J.W.F. and Rojas, X. (2016b) Dealing with discordance: A novel approach for analysing $\mathrm{U}-\mathrm{Pb}$ detrital zircon datasets. Journal of the Geological Society $173,577-585$.

Ríos, S., Salje, E.K.H., Zhang, M. and Ewing, R.C. (2000) Amorphization in zircon: Evidence for direct impact damage. Journal of Physics Condensed Matter 12, 2401-2412.

Salje, E.K.H., Chrosch, J. and Ewing, R.C. (1999) Is 'metamictization' of zircon a phase transition? American Mineralogist 84, 1107-1116. 
Sano, Y., Terada, K., Hidaka, H., Yokoyama, K., Nutman, A.P., (1999). Palaeoproterozoic thermal events recorded in the c.4.0 Ga Acasta gneiss, Canada: evidence from SHRIMP U-Pb dating of apatite and zircon. Geochimica et Cosmochimica Acta 63, 899-905

Satkoski, A.M., Wilkinson, B.H., Hietpas, J. and Samson, S.D. (2013) Likeness among detrital zircon populations-An approach to the comparison of age frequency data in time and space. Bulletin of the Geological Society of America 125, 1783-1799.

Sircombe, K.N., Bleeker, W. and Stern, R.A. (2001) Detrital zircon geochronology and grain-size analysis of a $\sim 2800 \mathrm{Ma}$ Mesoarchean proto-cratonic cover succession, Slave Province, Canada. Earth and Planetary Science Letters 189, 207-220.

Spencer, C.J., Kirkland, C.L. and Taylor, R.J.M. (2016) Strategies towards statistically robust interpretations of in situ U-Pb zircon geochronology. Geoscience Frontiers 7, 581-589.

Stacey, J.S. and Kramers, J.D. (1975) Approximation of terrestrial lead isotope evolution by a two-stage model. Earth and Planetary Science Letters 26, 207-221.

Stern, R.A. and Bleeker, W. (1998) Age of the world's oldest rocks refined using Canada's SHRIMP: the Acasta Gneiss Complex, Northwest Territories, Canada. Geoscience Canada 25, 27-31.

Stern, R.A., Bodorkos, S., Kamo, S.L., Hickman, A.H. and Corfu, F. (2009) Measurement of SIMS instrumental mass fractionation of $\mathrm{Pb}$ isotopes during zircon dating. Geostandards and Geoanalytical Research 33, 145-168.

Stern, T.W., Goldich, S.S. and Newell, M.F. (1966) Effects of weathering on the U/Pb ages of zircon from the Morton Gneiss, Minnesota. Earth and Planetary Science Letters 1, 369-371.

Tilton, G.R. (1960) Volume diffusion as a mechansim for discordant lead ages, Journal of Geophysical Research 65, 2933-2945.

Tera, F. and Wasserburg, G.J. (1972) U-Th-Pb systematics in three Apollo 14 basalts and the problem of initial Pb in lunar rocks. Earth and Planetary Science Letters 14, 281-304.

Weber, W.J. (1990) Radiation-Induced Defects and Amorphization in Zircon. Journal of Materials Research 5, 2687-2697.

Wetherill, G.W. (1956) Discordant uranium-lead ages, I. Eos, Transactions American Geophysical Union 37, 320-326.

Wiedenbeck, M., AllÉ, P., Corfu, F., Griffin, W.L., Meier, M., Oberli, F., Quadt, A.V., Roddick, J.C. and Spiegel, W. (1995) Three natural zircon standards for U-Th-Pb, Lu-Hf, trace element and REE analysis. Geostandards Newsletter 19, 1-23.

Zamyatin, D.A., Shchapova, Y.V., Votyakov, S.L., Nasdala, L. and Lenz, C. (2017) Alteration and chemical U-Th-total $\mathrm{Pb}$ dating of heterogeneous high-uranium zircon from a pegmatite from the Aduiskii massif, middle Urals, Russia. Mineralogy and Petrology 111, 475-497. 
Click here to download high resolution image
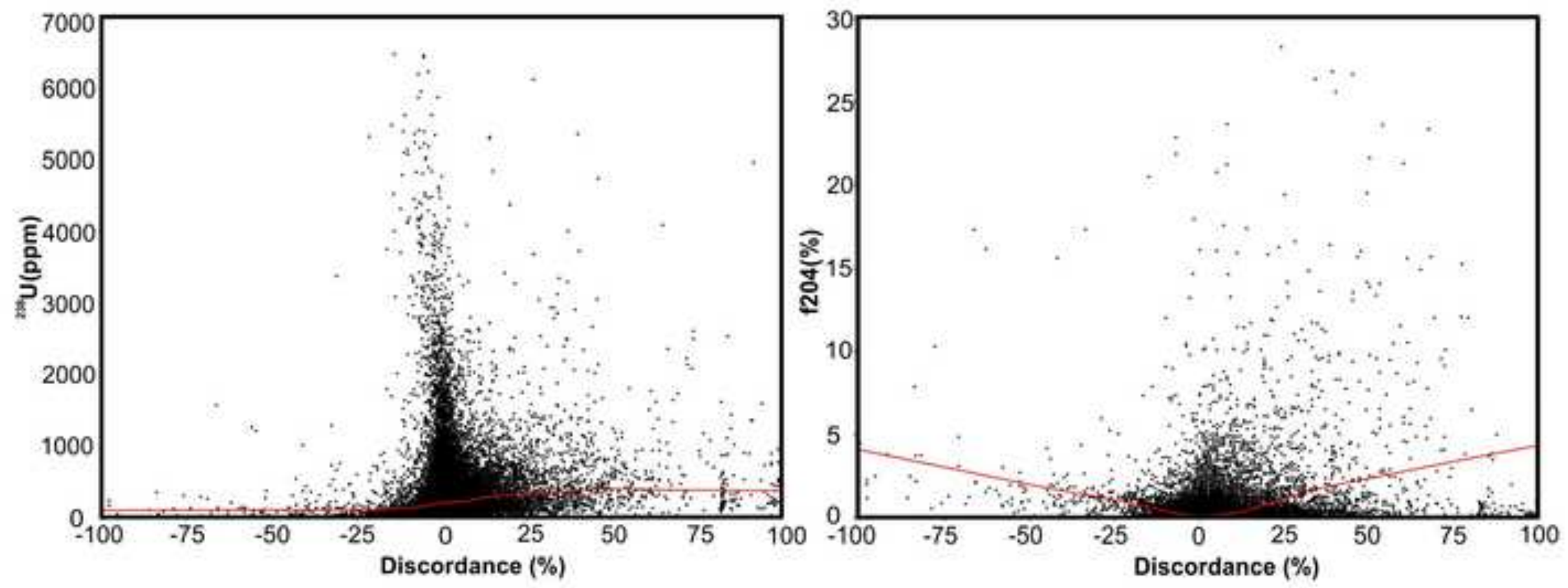
Click here to download high resolution image

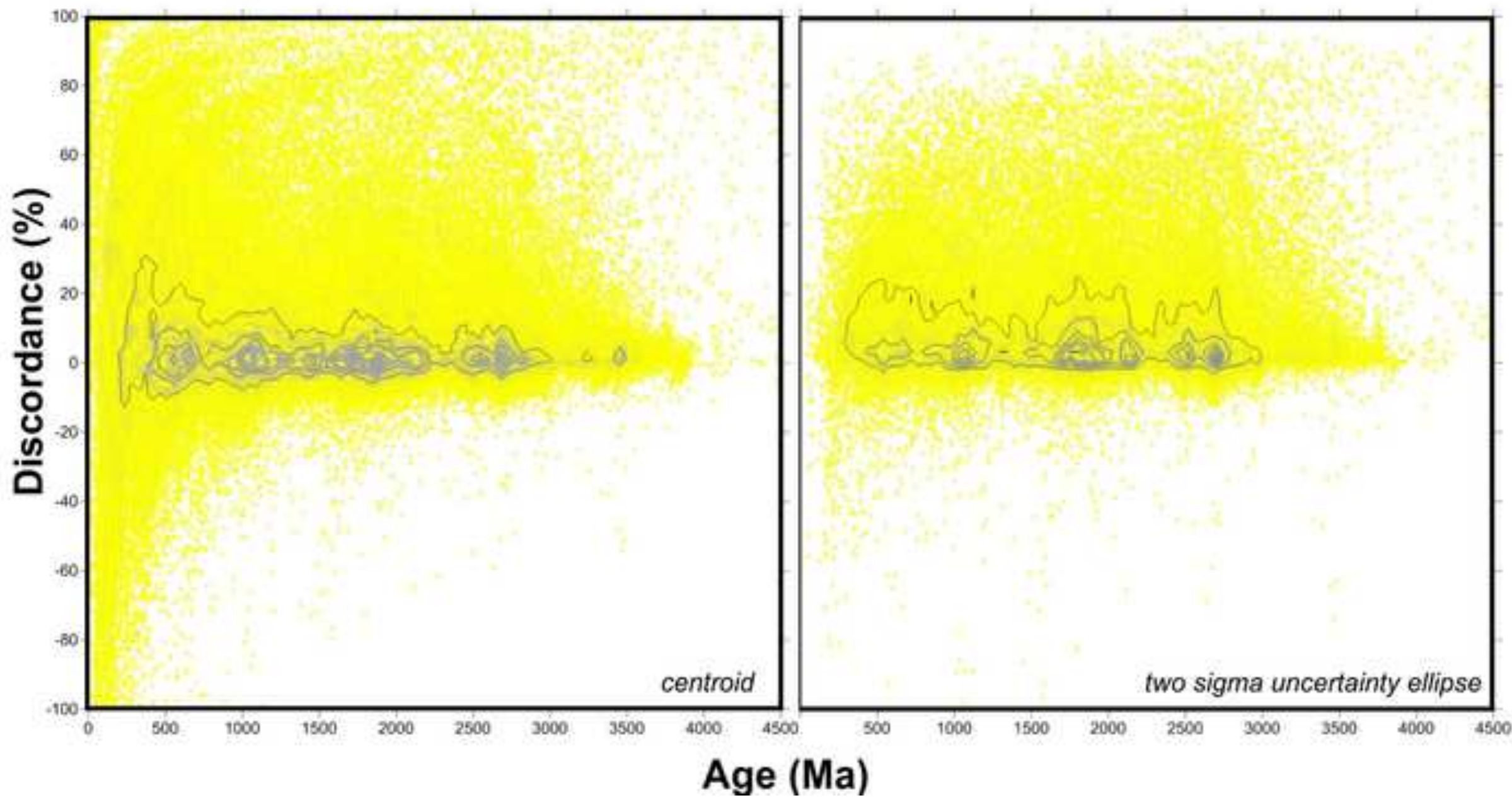



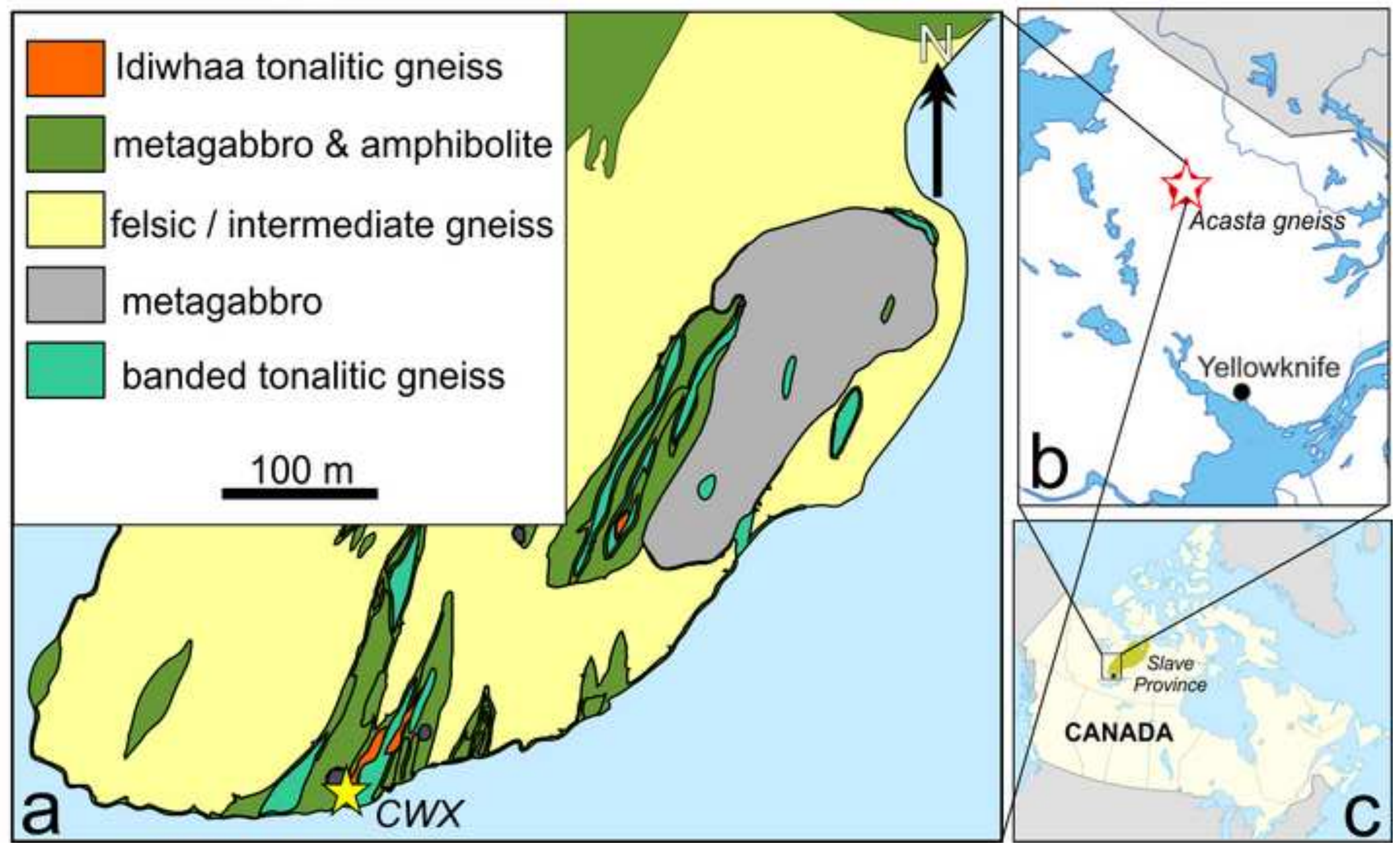
Click here to download high resolution image

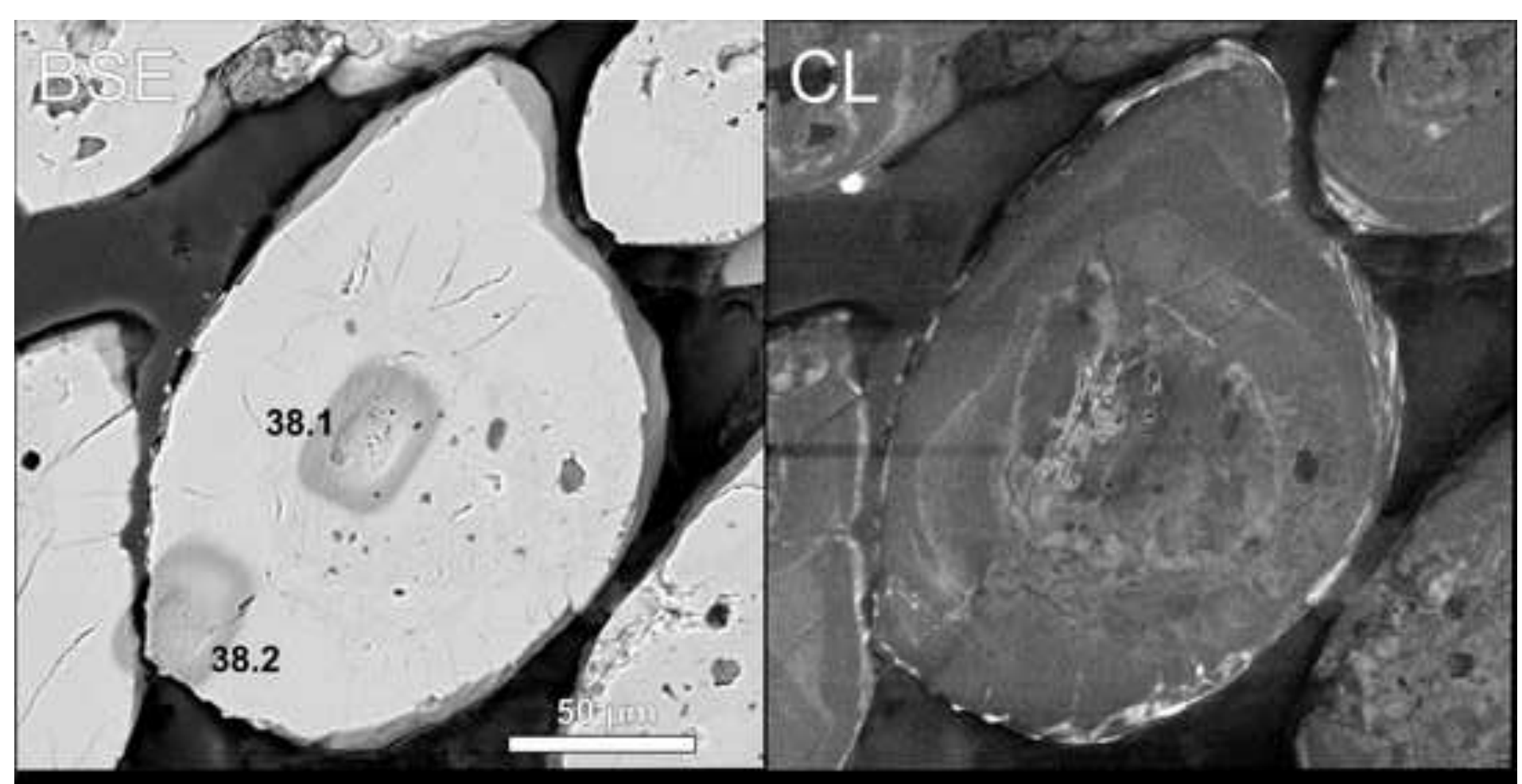

\section{BSE}

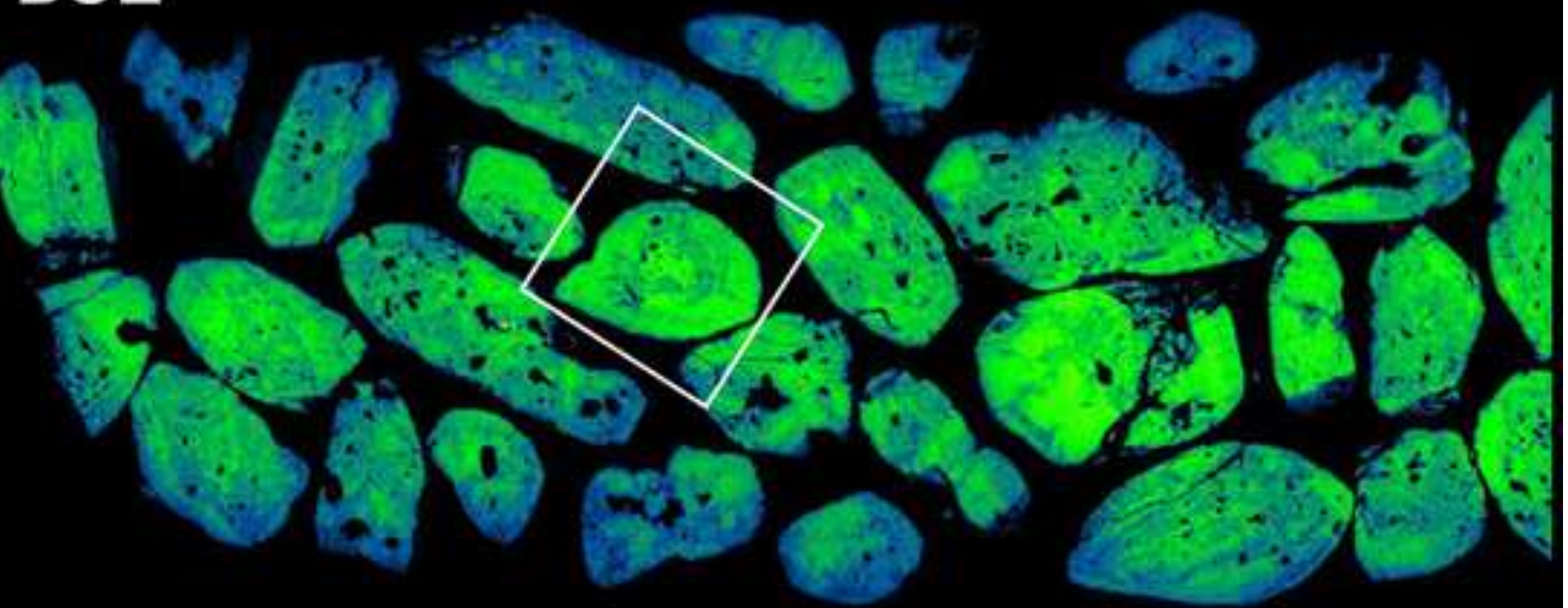




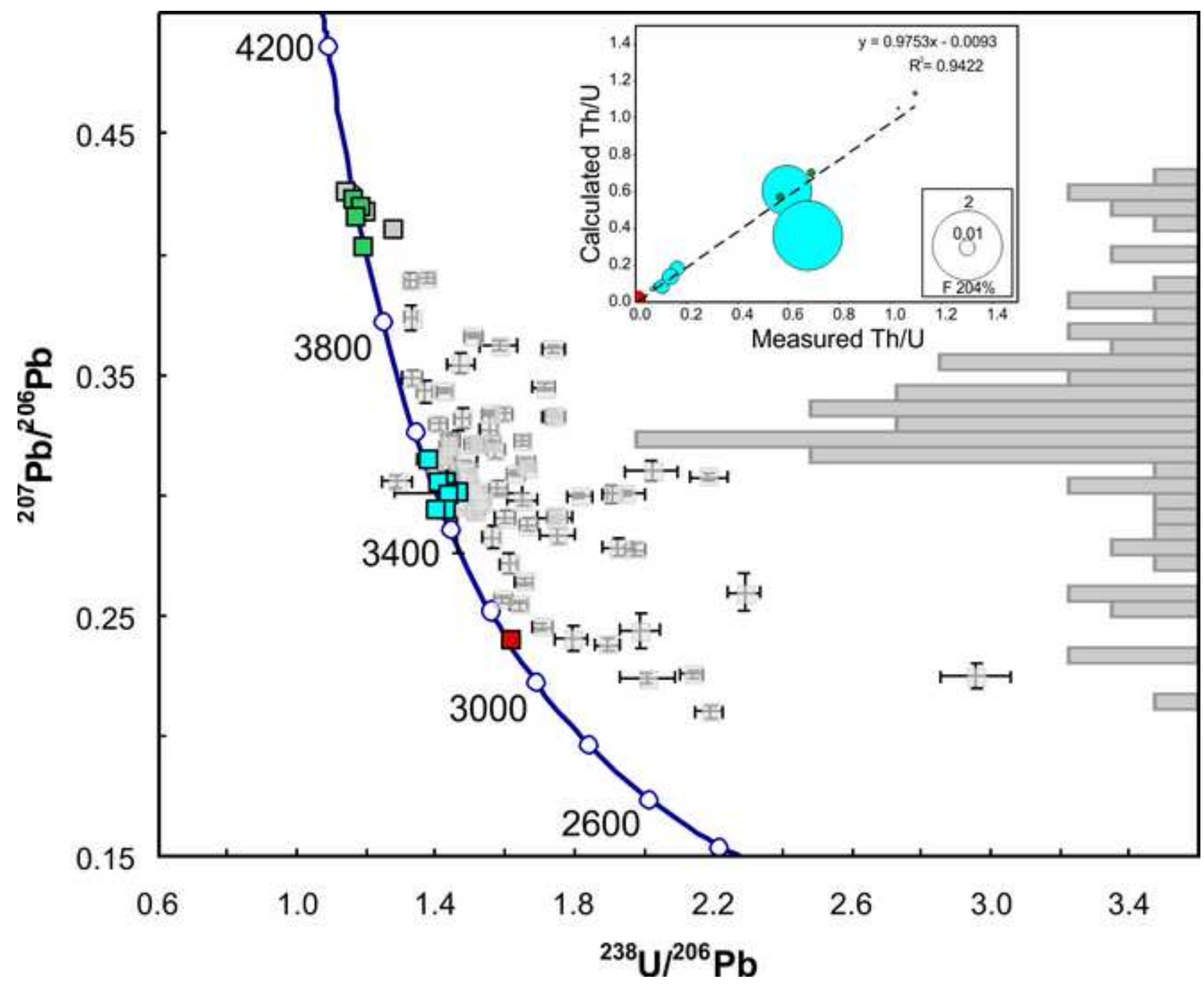




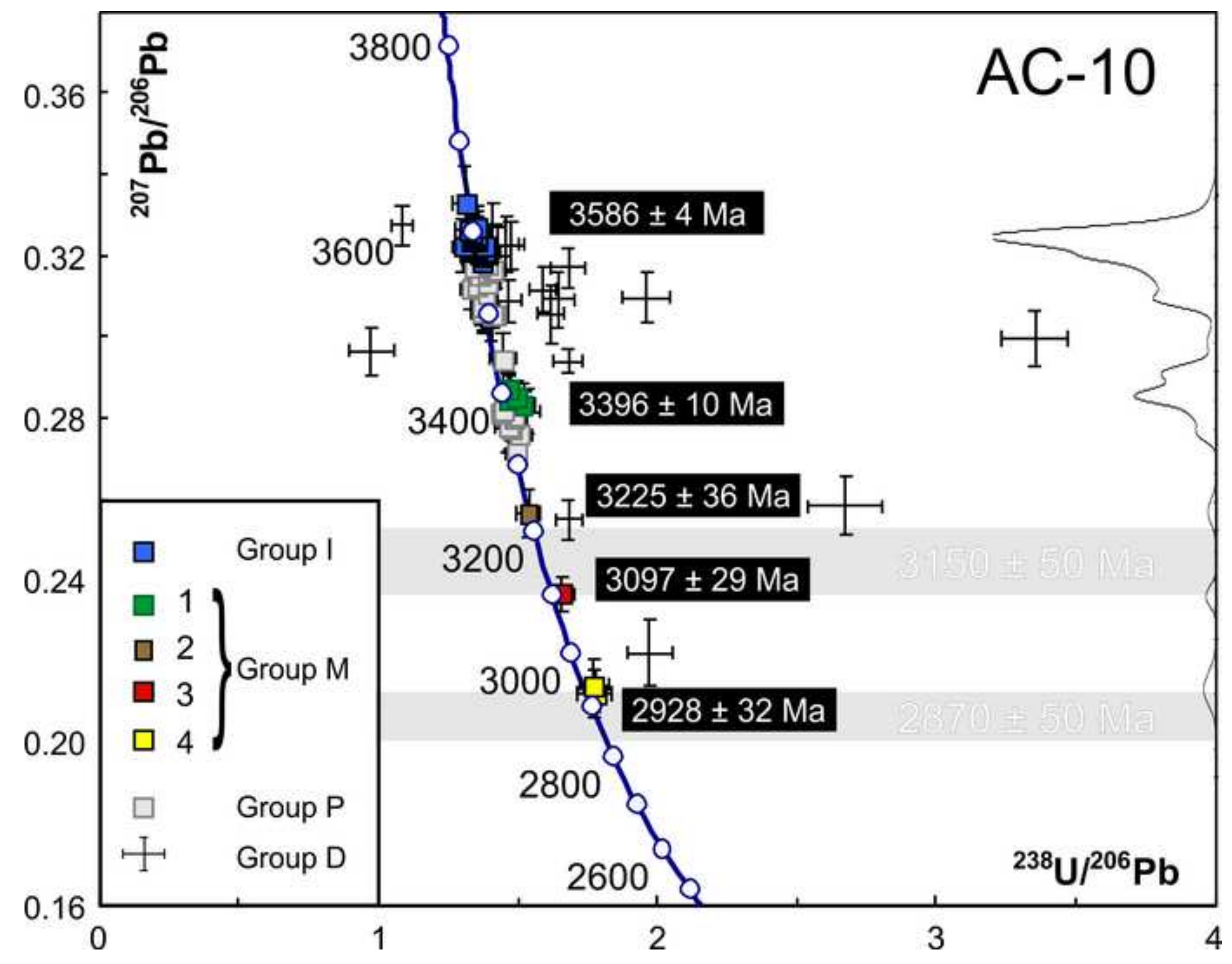




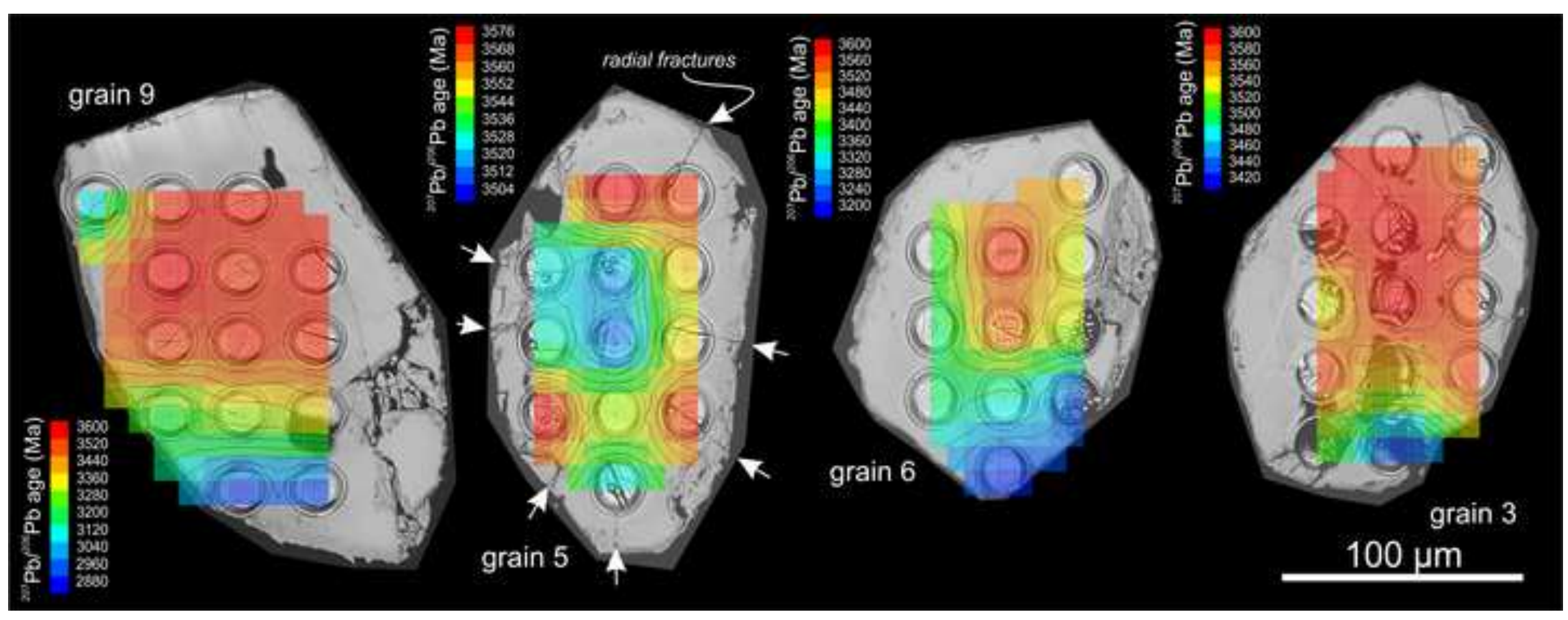


Click here to download high resolution image
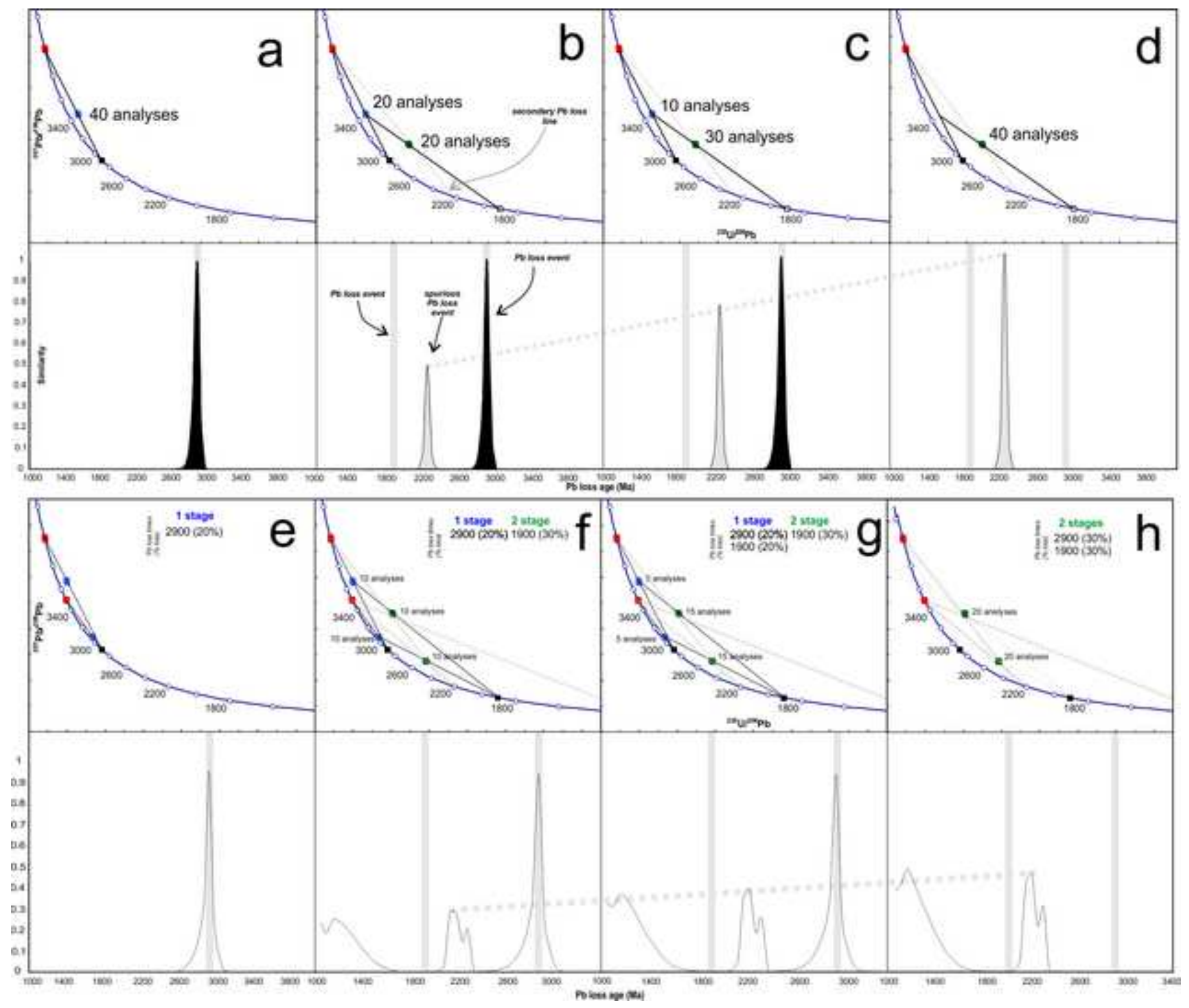


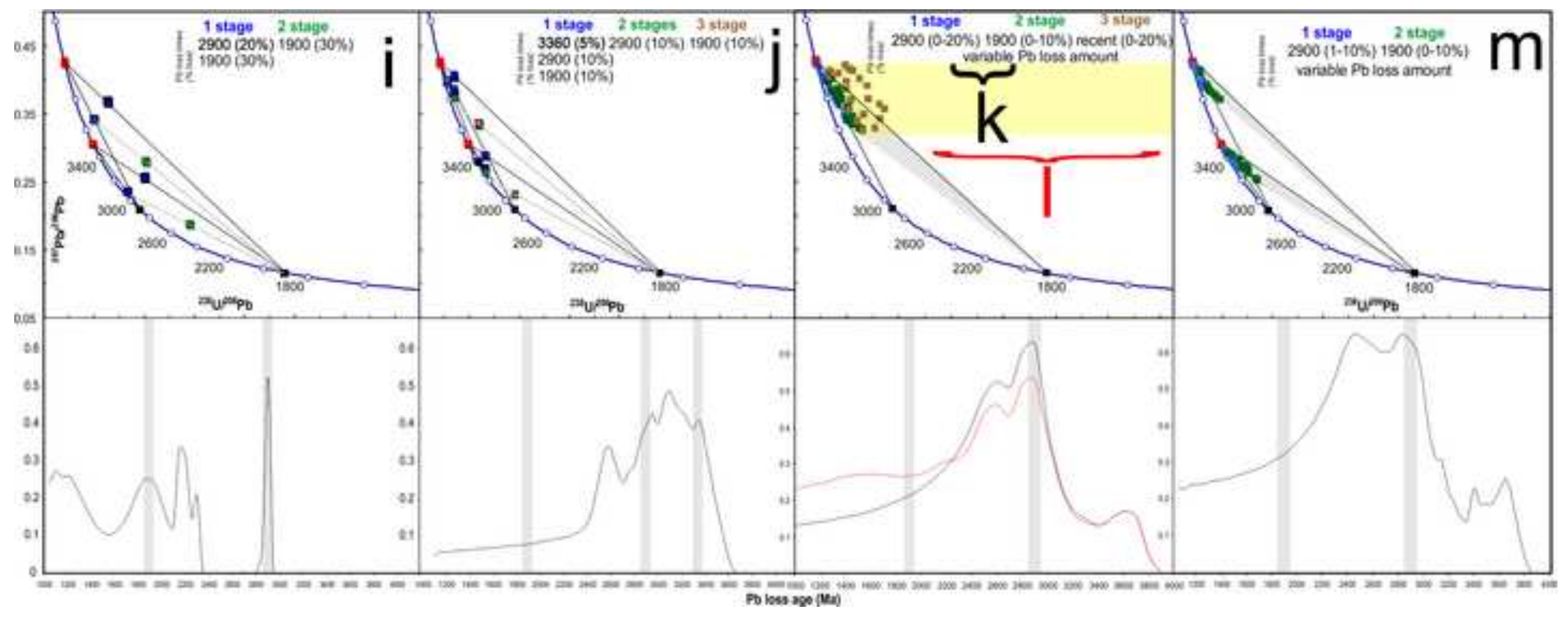




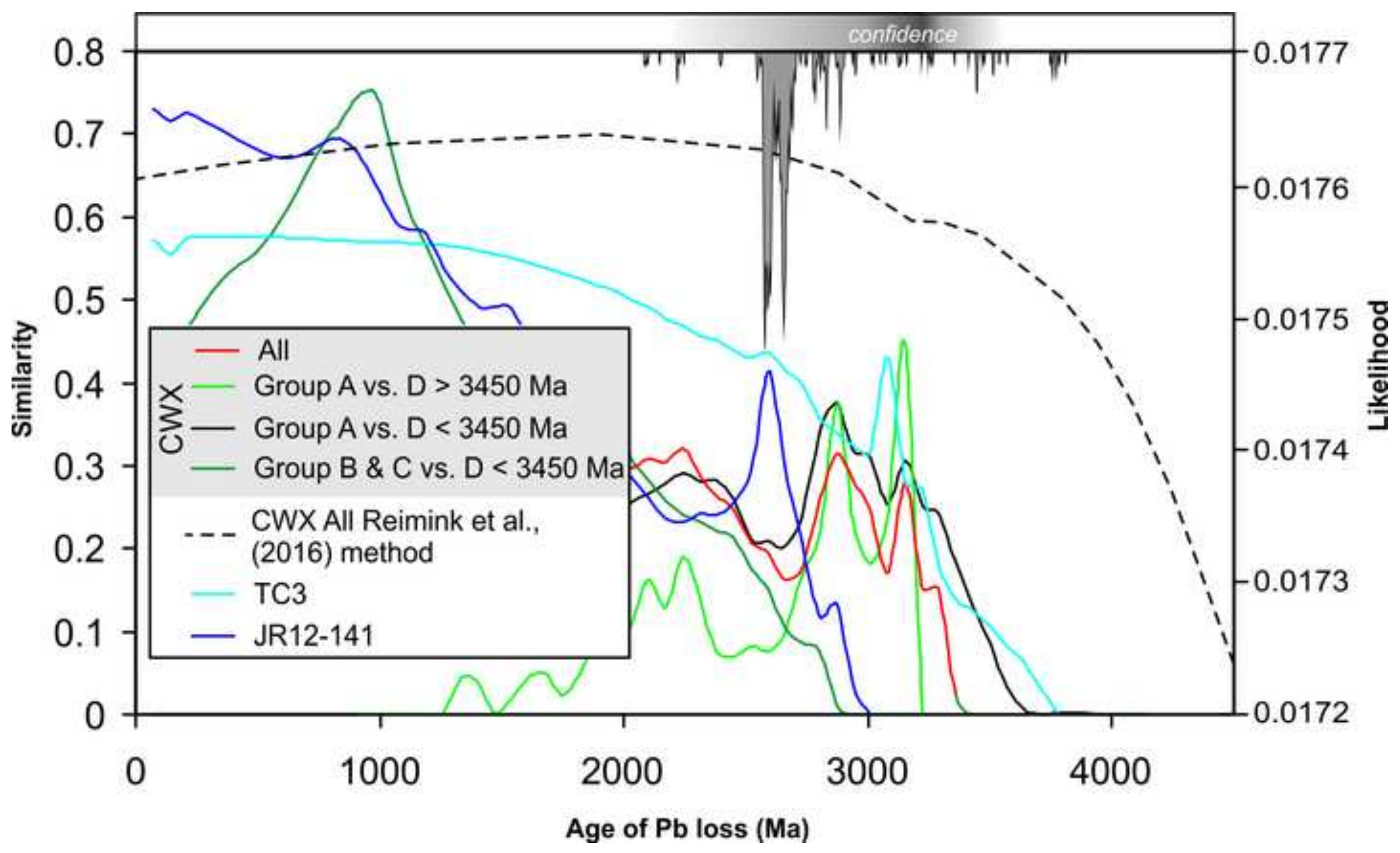




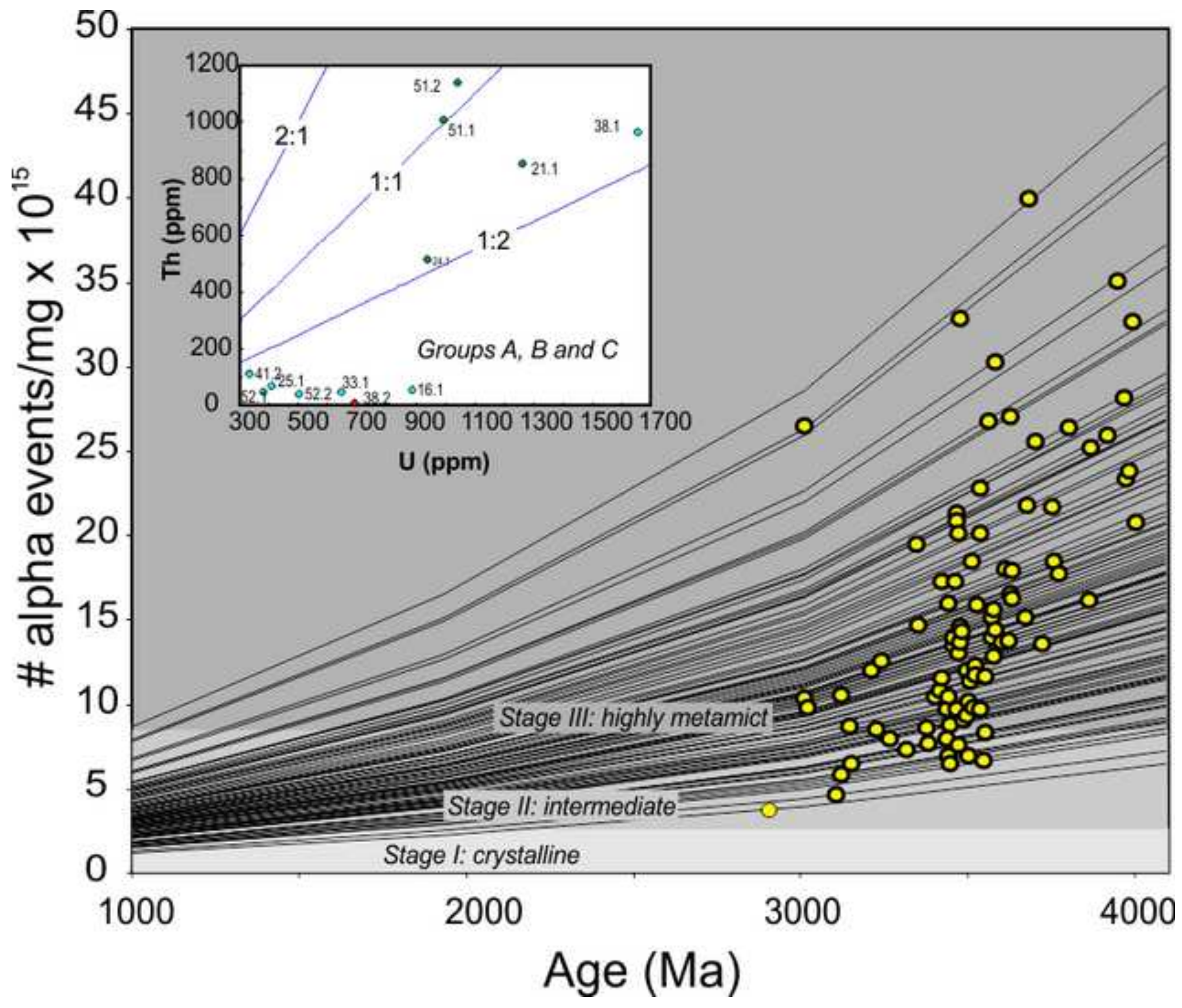




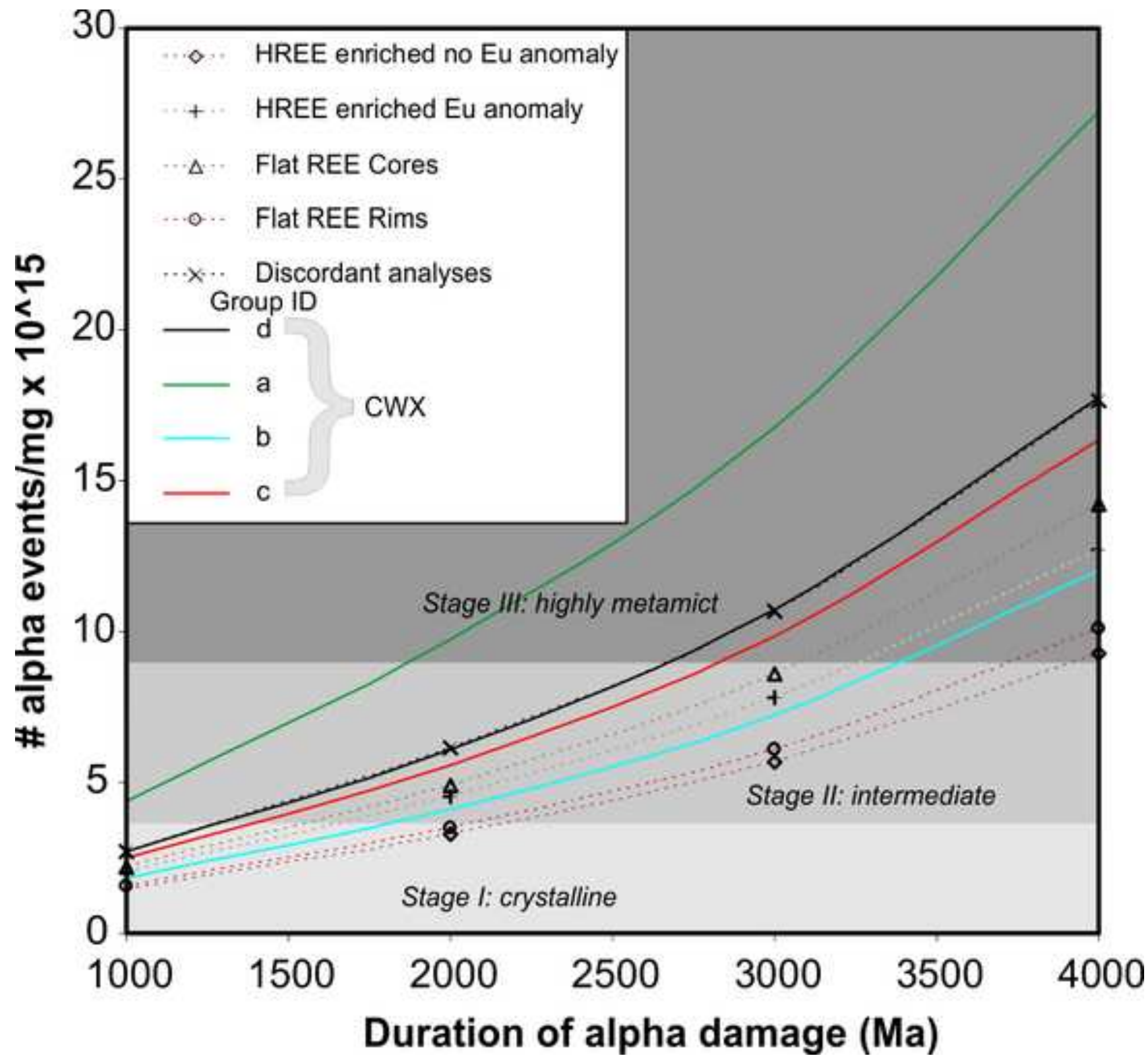



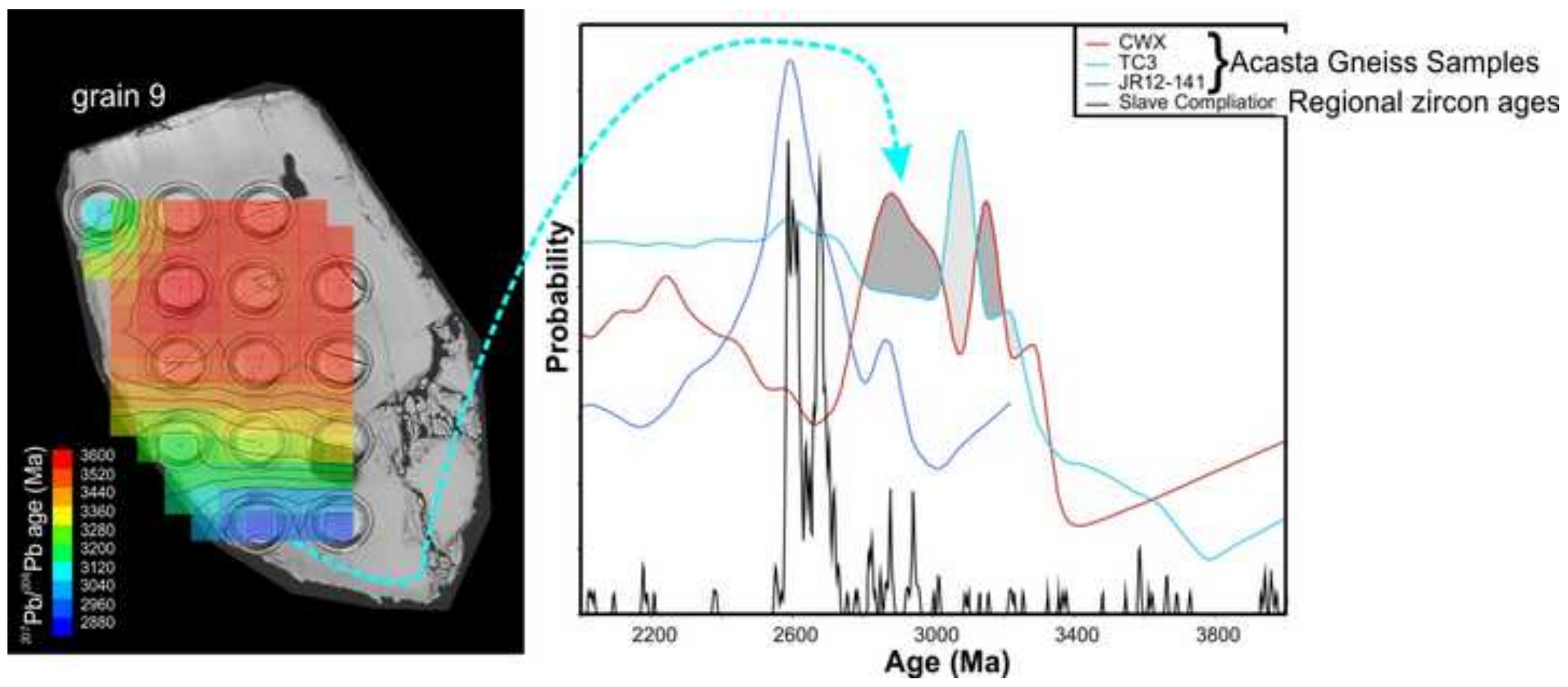